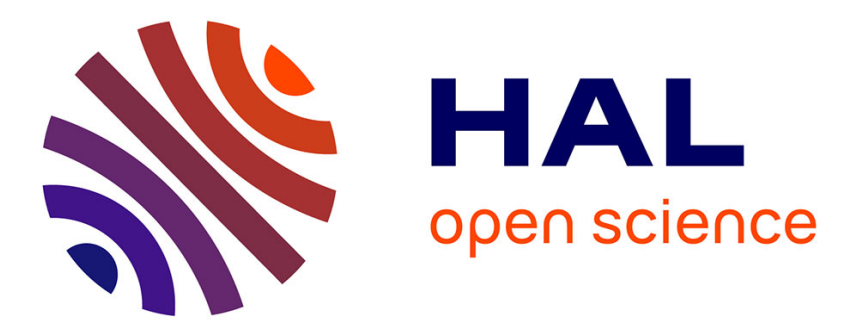

\title{
The Internationalization of American and Asian Automobile Firms: A Statistical Comparison with the European Companies.
}

\author{
Bruno Jetin
}

\section{- To cite this version:}

Bruno Jetin. The Internationalization of American and Asian Automobile Firms: A Statistical Comparison with the European Companies.. M. Freyssenet, K. Shimizu and G. Volpato (editors). Globalization or Regionalization of the American and Asian Car Industry?, Palgrave Macmillan, 2003. halshs-03208997v1

\section{HAL Id: halshs-03208997 https://shs.hal.science/halshs-03208997v1}

Submitted on 27 Apr 2021 (v1), last revised 1 May 2021 (v2)

HAL is a multi-disciplinary open access archive for the deposit and dissemination of scientific research documents, whether they are published or not. The documents may come from teaching and research institutions in France or abroad, or from public or private research centers.
L'archive ouverte pluridisciplinaire HAL, est destinée au dépôt et à la diffusion de documents scientifiques de niveau recherche, publiés ou non, émanant des établissements d'enseignement et de recherche français ou étrangers, des laboratoires publics ou privés. 
The Internationalization of American and Asian AutomobileFirms:

A Statistical Comparison with the European Companies

Bruno Jetin

\section{Introduction: internationalization, a necessary but risky adventure}

The internationalization of the automobile industry is a phenomenon that goes back a long way. Most automobile firms have tried to move into the international theatre within a few years of beginning operations, first through export activities and later by establishing overseas production facilities. However, internationalization has taken on a new dimension in the context of economic globalization. The reinforcement of free trade, new rights guaranteeing the mobility of productive and financial capital, and the intensification of competition in the firms' original markets - all these factors have induced companies to try to use internationalization as a solution to the structural problems they face.

In the developed countries, the slowdown in growth, rising inequalities, the predominance of a product-replacement type of demand, and even demographic trends, have combined to make it harder to produce and sell an ever-greater volume of motor vehicles.

The profitability constraint has also become more severe. To better anticipate or adapt to demand (and to the increased number of environmental and safety-related standards), the new models that are being launched are increasingly differentiated. However, this has led to a rise in investment outlays at a time when greater competition squeezes profit margins, causing shareholders to demand greater remuneration.

The solution to these problems can no longer be found within a national market that exists in isolation. Conversely, by making sales in as many markets as possible, some of the aforementioned constraints can be loosened.

Growth rates in the 'three poles of the Triad' (North America, Japan and the European Union) became more uncoupled during the 1990s than during the 1970s and 1980s. Renewed growth in the United States between 
1991 and 2000 enabled certain Japanese and European firms to make substantial profits, which in certain cases supplemented the profits (or offset the losses) they were making in their domestic markets.

The so-called 'emerging' countries experienced rapid growth up to 1997. For the first time since the 1970s, the emerging markets' enormous potential translated into high real demand. Firms that were ready for this scenario were able to make a lot of money in these parts of the world.

To take advantage of these overseas profit opportunities without reviving protectionist tendencies (and to satisfy demand to a maximum extent while minimizing costs), most automakers were forced to manufacture in the same places as they were making their sales. This created a veritable investment race (notably in the so-called 'emerging' countries). This drive could be meaningful at the individual firm level, but at a global level it translated into a further increase in the excessive production capacities from which the automobile sector was already suffering.

According to certain estimates (PricewaterhouseCoopers, 1999), production capacities grew by 17 million units between 1990 and 1997, the equivalent of an additional North American market. This can be explained by the rapid growth of automobile demand from the 'emerging' countries up to 1997, and from the North American market until 2000. But what remained of this legacy once economic crisis struck the emerging countries (1997-8) and growth slowed down in the developed countries (2001)?

Calculated at a global level, unused production capacities were estimated to be 30\% in 1990 and 39\% in 1999 (PricewaterhouseCoopers, 1999; Economist Intelligence Unit, 2000). However, this average covers significant geographic variations: 40\% in Asia in 1998 (PricewaterhouseCoopers, 1999);

56\% in Brazil in 1999 (Financial Times Auto Survey, 2000); and 65\% in Argentina in 1999 (Ward's Automotive Yearbook, 2000). At first glance, it would appear that firms that are present in all regions of the world are best able to absorb those demand shocks that can engender major financial losses. However, firms with a low level of geographic diversification can also suffer greatly in such situations, and even go bankrupt. When a fall-back in growth also affects the firm's country of origin, which often remains its main market, doubts can be raised about the viability of its overseas operations. As such, the late 2000 decline in American growth led immediately to the closure of a number of American automakers' overseas plants as they tried to restore profits as soon as possible to regain shareholder confidence.

Internationalization increases firms' vulnerability to cyclical fluctuations in growth. For this reason, it is at best a positive strategy for a few firms; but certainly not for all. It is from this perspective that the present chapter will try to develop a quantitative analysis of the internationalization of firms. 
We shall be attempting to answer two fundamental questions:

1. What are firms' current levels of internationalization? Is there really such a thing as a 'global' firm?

2. How do international activities contribute to firms' profits (or losses)?

Although quantitative analysis cannot in and of itself answer these questions, it nevertheless constitutes a good starting point and can be supplemented by the qualitative analysis this book's other chapters offer.

At a methodological level, this quantitative analysis will exploit systematically long-term data that firms have published in their financial reports. Some will argue that this data is inconsistent because it is subject to firms' desire to publish information that is reliable within accounting and legislative frameworks which can vary over time and from one country to another. Nevertheless, and despite the difficulty of achieving total precision, we still feel that our findings correspond to the known characteristics of the firms under study, and to the events that have affected them.

In addition, this quantitative investigation will be based on the following hypotheses:

1. It will be postulated that multinational firms are not 'footloose'; rather that they are dependent upon their territory of origin, which provides them with economic and institutional support. This territory might be the firm's country of origin but it can also be the region, even if the process of regional integration varies greatly from one continent to another. Depending on the particular example, internationalization will be defined as all the activities situated outside a firm's country or region of origin.

2. Multinational automobile firms are to be considered as industrial and financial groups in addition to their car-making activities. This is indeed the relevant level of analysis for studying all of a firm's financial flows and sources of profit, rather than their physical production of passenger cars alone. Whereas, in most firms, passenger cars and commercial vehicles represent $80 \%$ to $90 \%$ of (external) revenues, there are significant exceptions. As an example, passenger cars and commercial vehicles only accounted for $55 \%$ of the Fiat Group's revenues in 1997-9; the 'motorcycle' branch accounted for $14 \%$ of Honda and Suzuki's revenues in 1995-9; and services represented $18.5 \%$ of Ford's revenues in 1996-8.

Given these hypotheses, the present chapter will be organized in the following manner: the next section is an inventory presenting the level of concentration that characterizes the world's automobile industry. We shall then measure the extent of firms' commercial internationalization, and subsequently their level of productive and financial internationalization. We shall conclude this section with a presentation of two synthetical indexes. The following section then focuses on the contributions that overseas activities 
make to firms' world-wide profits (or losses). In particular, we shall look at American, Japanese and French firms. ${ }^{1}$

\section{The inventory}

A sector's degree of internationalization is a multi-faceted phenomenon. Just using a criterion such as assets held abroad in 1998 (calculated in absolute terms), we find no less than nine automobile firms among the world's twenty -five leading multinationals (UNCTAD, 2000). Automobile firms also lead the tables in areas such as foreign sales volumes (in absolute terms) and number of overseas staff members. This is because they are among the world's largest multinational firms. If we analyse overseas business as a proportion of total activities by combining several criteria (following the UNCTAD index's transnational logic), we can see that there has been a substantial rise in the automobile industry's degree of internationalization. ${ }^{2}$ In 1990 , the transnationality index was at $35.8 \%$, far behind the $51.1 \%$ average (all sectors combined) for the world's 100 leading multinational firms. By 1998, the automobile industry's transnationality index had risen sharply, reaching $49 \%$ and approaching the average index value of $53.9 \%$. This was still behind the values for industries such as media $(86.7 \%)$, food and drink (74.3\%), pharmaceuticals $(64.3 \%)$, chemicals $(58.5 \%)$, and even oil $(52.7 \%)$ (UNCTAD, 2000). But it is clear that the automobile industry has been experiencing a recent acceleration in its internationalization levels, thus raising questions about the existence of qualitative changes in its supply structure and forms of competition.

\section{The constitution of a space of global competition}

The automobile industry was not left untouched by the wave of mergers/acquisitions and partnerships that affected all industrial activities and services during the late 1990s. This led to a rapid rise in concentration a development shown in Table 2.1, with its analysis of changes in the output of the world's twenty largest firms between 1985 and 1999.

Table 2.1 Changes in the level of concentration of the world automobile industry, 1985-99

\begin{tabular}{|c|c|c|c|c|}
\hline \multicolumn{5}{|c|}{ Production volume Number of firms $\%$ of world output } \\
\hline (mIIIIon & 1985 & $\begin{array}{l}199 \\
9\end{array}$ & 1985 & 1999 \\
\hline $4-9$ & 3 & 6 & 42.2 & 65.1 \\
\hline $2-3$ & 2 & 4 & 11.6 & 17.3 \\
\hline $1-2$ & 8 & 4 & 27.8 & 9.3 \\
\hline$<1$ & 7 & 6 & 9.3 & 4.3 \\
\hline Total & 20 & 20 & 90.9 & 96.0 \\
\hline
\end{tabular}

Sources: Calculated with data from the Comité des Constructeurs Français d'Automobiles (CCFA, 1999); and the Motor Vehicle Manufacturing Association (MVMA, 1985). 
We see that, in 1985, three firms manufactured more than 4 million units, representing $42.2 \%$ of world output. ${ }^{3}$ By 1999 , six firms were producing more than 4 million units, and controlling $65.1 \%$ of global production. ${ }^{4}$

In 1985, two firms made between 2 million and 3 million units, representing $11.6 \%$ of world output. ${ }^{5}$ By 1999 , four firms were in this situation, representing $17.3 \%$ of world output. ${ }^{6}$ Eight firms produced between 1 million and 2 million units, representing $27.8 \%$ of 1985 totals. ${ }^{7}$ By 1999 , this was down to four firms, representing $9.3 \%$ of world output. $^{8}$ Finally, seven firms were producing between 400,000 and 700,000 units in 1985 , representing $9.3 \%$ of world output. ${ }^{9}$ Six firms fitted into this category fourteen years later, only accounting for $4.3 \%$ of global production. ${ }^{10}$

This trend towards concentration, which has accelerated with the process of globalization, raises questions about the very nature of the automobile industry. Has this sector become a 'global industry', with the meaning that M. Porter lends to this term (1986) - that is, an industry where not only are domestic markets so integrated that they form a unified market at the global level, but where firms themselves have integrated their activities world-wide, leading to the constitution of a global oligopoly? If this is the case, the six firms that produce more than 4 million units enjoy a crucial competitive advantage thanks to the economies of scale and scope they can obtain across the world - and thanks to the global integration of their innovation activities. However, the failure of the firms that have attempted to market 'world cars' and the difficulties encountered during attempts to integrate the engineering departments of the many subsidiaries located across the world's different continents demonstrates that although competition has indeed become global, the automobile firms themselves are not globally integrated companies.

As such, our six leaders do not comprise a new and definitively established global oligopoly, inasmuch as they still have to transform their relatively larger size into a real competitive advantage, notably by sharing platforms and by commonalizing components on a global scale. Yet recent experience shows that only a small percentage of mergers/acquisitions in fact succeed (The Economist, 1999). In the automobile industry, there have been a number of recent failures, casting doubts on the inevitability and sustainability of a global oligopoly made up of five or six automakers (Lung, 2000). The smaller firms, especially those that refuse to participate in this concentration trend, are not condemned irremediably.

The concept of a global oligopoly must therefore not be defined as a 'supply structure' that has been established once and for all. Instead, it should be defined as a 'space of industrial rivalry' (Chesnais, 1994), which 'is bordered by a type of interdependency relationship that creates linkages between the small number of large groups within a particular industry who have succeeded in acquiring and maintaining the status of someone who can compete effectively at the global level'. This is an 'area of intense competition' born out of mutual invasion strategies, 'but 
also out of inter-group 
collaboration' (Friedman, 1983). The oligopoly is global in nature because of these competition-based relationships, even if its industrial foundations are not global (in fact, they are usually regional).

This definition seems to us to be very useful for analysing automobile firms' current stage of internationalization, inasmuch as commercial internationalization is generally more advanced than productive internationalization.

This is what we shall try to verify by analysing three forms of internationalization on the basis of five quantitative criteria. The proportion of total revenues realized outside the country of origin comprise an indicator we shall call 'commercial revenues'. ${ }^{11}$ This makes it possible to measure the degree of firms' commercial internationalization. The proportion of revenues 'produced' by subsidiaries located outside the country of origin, called 'production revenues', and the proportion of complete vehicle production carried out outside the country of origin, are factors that will help us to measure productive internationalization. ${ }^{12}$

\section{Commercial internationalization is the automobile firms' most advanced form}

UNCTAD (2000) studies have demonstrated that commercial internationalization has only developed in recent times. In 1993, the top 100 multinational enterprises (MNEs), all sectors of activity combined, still relied for $57 \%$ of their business on their national market. Nevertheless, commercial internationalization has been growing rapidly and represents the vanguard of the internationalization process. Foreign markets reached $52 \%$ in 1997-8. According to the same sources, the automobile sector, with $57.2 \%$, is clearly above the average for all sectors and thus appears, at a commercial level, to be one of the world's most internationalized industries. ${ }^{13}$

This analysis could be enhanced by incorporating an even greater number of firms; their national origins; and the diversity of the commercial strategies they have adopted. Our own sample, comprising twenty-one firms, satisfies this objective by offering a more comprehensive vision of the automobile industry (albeit one that remains incomplete). ${ }^{14}$ In 1995-9, the American firms analysed in Table 2.2 realized an average $51.3 \%{ }^{15}$ of their total sales outside their country of origin. Note the American firms' low level of internationalization (average $24.5 \%)$, far behind the Japanese (57\%) and above all the European $(72.5 \%)$, averages. For this latter subset, the domestic market is no longer the main market.

American firms' low level of commercial internationalization is surprising given that ever since the early twentieth century GM and Ford, the world's top two automakers, have been running the world's largest overseas operations (in absolute terms), primarily in Europe. It is also surprising given that Navistar is the world's second leading maker of commercial vehicles. The extremely large size of the North American market is one natural reason for this paradoxical result, but it does not 
explain everything. General Electric, 
Table 2.2 Comparison of the degree of internationalization of automobile firms, 1995-9, and synthetical index, as percentage of total

\begin{tabular}{|c|c|c|c|c|c|c|c|}
\hline \multirow[t]{2}{*}{ Firms } & \multicolumn{5}{|c|}{$\begin{array}{l}\text { Degree of internationalization } \\
\text { of automobile firms, 1995-9 }\end{array}$} & \multicolumn{2}{|c|}{$\begin{array}{l}\text { Synthetical index } \\
\text { internationalization }\end{array}$} \\
\hline & $\begin{array}{l}\text { Commercial } \\
\text { revenues }\end{array}$ & $\begin{array}{l}\text { Productive } \\
\text { revenues }\end{array}$ & Production & Workforce & $\begin{array}{l}\text { Total } \\
\text { asset } \\
\mathrm{S}\end{array}$ & Global & UNCTAD \\
\hline \multicolumn{8}{|l|}{ American firms } \\
\hline Chrysler (95-97) & 13.1 & n.d. & 37.7 & 17.0 & 14.8 & 20.7 & 15.0 \\
\hline Ford (95-97) & 34.2 & n.d. & 46.0 & 48.2 & 26.0 & 38.6 & 36.1 \\
\hline Navistar (96-98) & 8.8 & n.d. & 27.3 & 11.0 & 8.6 & 13.7 & 9.5 \\
\hline GM (95-96) & 30.4 & n.d. & 45.1 & 32.8 & 26.9 & 33.8 & 30.0 \\
\hline Paccar (96-99) & 36.2 & n.d. & 33.6 & n.d. & 49.3 & n.d. & n.d. \\
\hline Average (1) & 27.4 & n.d. & 38.0 & 30.7 & 27.7 & 28.7 & 25.2 \\
\hline Average (2) & 32.3 & n.d. & 45.6 & 40.5 & 26.5 & 36.2 & 33.1 \\
\hline \multicolumn{8}{|l|}{ European firms } \\
\hline $\mathrm{BMW}(95-99)$ & 72.0 & n.d. & 49.1 & 41.1 & 61.7 & 56.0 & 58.3 \\
\hline Daimler-Benz (95-97) & 61.1 & 47.5 & 46.7 & 23.4 & 38.0 & 42.3 & 40.8 \\
\hline DaimlerChrysler (95-97) & 81.3 & n.d. & 77.0 & 47.5 & 73.4 & 69.8 & 67.4 \\
\hline Fiat Auto (95-99) & 58.9 & n.d. & 41.2 & 34.1 & 41.7 & 44.0 & 44.9 \\
\hline Fiat Group (95-99) & 62.7 & 38.4 & 41.2 & 39.7 & 45.3 & 47.2 & 49.2 \\
\hline PSA (95-99) & 60.7 & 50.8 & 22.9 & 24.3 & 39.3 & 36.8 & 41.4 \\
\hline Renault (95-99) & 58.2 & 45.7 & 27.2 & 30.8 & 48.5 & 41.2 & 45.8 \\
\hline Scania (95-99) & 90.0 & n.d. & 74.0 & 50.4 & n.d. & n.d. & n.d. \\
\hline VW (95-99) & 64.6 & 35.6 & 53.2 & 47.0 & 58.3 & 55.8 & 56.6 \\
\hline Volvo (95-99) & 90.4 & n.d. & 68.1 & 43.5 & n.d. & n.d. & n.d. \\
\hline Average (3) & 72.5 & 34.1 & 51.6 & 40.5 & 54.4 & 51.1 & 53.1 \\
\hline Average (4) & 62.9 & 44.0 & 45.1 & 37.5 & 53.8 & 50.6 & 52.4 \\
\hline
\end{tabular}


Firms

Degree of internationalization

of automobile firms, 1995-9

\begin{tabular}{ccccc}
\hline $\begin{array}{c}\text { Commercial } \\
\text { revenues }\end{array}$ & $\begin{array}{c}\text { Productive } \\
\text { revenues }\end{array}$ & Production & Workforce & $\begin{array}{l}\text { Total } \\
\text { asset } \\
\text { s }\end{array}$ \\
\end{tabular}

s

\section{Japanese firms}

Honda (95-99)

Isuzu (96-99)

Mazda (95-99)

Mitsubishi (95-99)

Nissan (95-99)

Subaru (95-99)

Suzuki (95-99)

Toyota (95-99)

Average (5)

$\begin{array}{lll}69.2 & 64.9 & 46.9 \\ 59.7 & 35.6 & 41.8 \\ 60.6 & 36.8 & 17.9 \\ 52.5 & 32.9 & 29.8 \\ 56.0 & 51.6 & 39.7 \\ 52.1 & 39.2 & 16.6 \\ 50.7 & 22.7 & 36.8 \\ 53.5 & 43.3 & 31.0 \\ \mathbf{5 6 . 8} & \mathbf{4 0 . 9} & \mathbf{3 1 . 2}\end{array}$

73.2
55.5
24.0
29.7
71.0
34.7
n.d.
59.8
$\mathbf{4 8 . 7}$

53.6

10.6

16.9

30.4

37.6

25.9

18.1

42.9

29.5
60.7

41.9

29.9

35.6

51.1

32.3

n.d.

46.8

42.7

Synthetical index internationalization

Global UNCTAD

Notes: The Global Synthetical Index is an average of the Commercial Revenues, Production, Total Assets, and Workforce Indexes. The UNCTAD's Synthetical Index is an average of the Commercial Revenues, Workforce and Total Assets Indexes. Average (1) is calculated with all American firms. Average (2) is calculated with Ford and GM only. Average (3) is calculated with all European firms except Fiat Auto and DaimlerBenz. Average (4) concerns BMW, DaimlerChrysler, Fiat Auto, PSA, Renault and VW. Chrysler's and Daimler-Benz's results are given for information. Average (5) is calculated with all Japanese firms. Italic figures are for 1995-8 only. Total assets for the Fiat and VW groups are estimations. VW's productive revenues are 1995-7 only. 
which in 1998 was the world's leading multinational (in terms of total assets) makes $28.6 \%$ of its total sales overseas, a percentage comparable to GM and Ford - yet at the same time overseas sales represented $56.8 \%$ of IBM's total sales in 1998 (UNCTAD, 2000). In addition, we could have expected American firms to take greater advantage than their colleagues of their large size in order to develop their commercial presence across the world.

It remains that GM's and Ford's repeated efforts to standardize their global product range are hampered by the still highly heterogeneous nature of the preferences shown in the demand that emanates from the world's different continents, for both passenger cars and commercial vehicles. This hampers an otherwise very real chance to share components and achieve economies of scale. For example, light truck volumes in North America are higher than the volumes achieved with the infamous 'world cars'. American firms have therefore been forced to market products that are specific to each continent, thus reducing their opportunity to leverage the size advantage they have acquired in the American market in their internationalization efforts, and leaving themselves more exposed to foreign competition. This explains the highly stable geographical spread of North American firms' commercial revenues, with a predominant proportion of total sales being realized in the North American and European markets.

In 1970-9, North America accounted for $71 \%$ of Ford's commercial revenues, Europe 23\%, South America and Asia/Africa/Pacific around 3\% respectively. ${ }^{16}$ By the 1990s, this breakdown had remained practically identical, despite globalization. ${ }^{17}$ GM's experience is comparable, except for the fact that it involved an even greater initial dependency on the North American market (84.2\% of the firm's commercial revenues) from 1971 to 1979. Europe only accounted for $10.3 \%$ at the time, and the rest of the world 5.5\%. In 1990-9, this was rebalanced in favour of Europe (19.2\%), with NAFTA's share dropping to $75.4 \%$. The rest of the world's share of GM's total sales remained identical, with around 3\% for South America and 3\% for Asia/Africa/Pacific. GM and Ford thus present a similarly bipolar geographic spread, with a strong focus on developed Western countries. The two firms have been unable to develop their market share in South America (despite the US government's very strong influence in this region), and even less so in Japan and the rest of Asia, despite the fact this latter region experienced the world's

fastest rate of growth over the period of time in question.

Diametrically opposed to the American example, European firms feature a very high degree of commercial internationalization (with an Average (3) of $72.5 \%$ in Table 2.2). This can be explained partially by the smaller size of the European national markets. From the very outset local automakers have been forced to engage in export activities so as to discover the additional volumes they need abroad (and particularly in their neighbouring countries) to achieve economies of scale. This is particularly true for Swedish firms which, faced with a very narrow domestic market, realize $90 \%$ of their 
total sales outside Sweden, unlike American and Japanese commercial vehicle manufacturers, who feature a very low degree of internationalization. ${ }^{18}$ Even outside this particular sub-set of firms, European generalist automakers' degree of internationalization remains high, with nearly $63 \%$ of sales being made outside the country of origin (cf. Average (4) in Table 2.2). As such, the European market has become a natural battleground for competition, much like the entity that NAFTA has created in North America. Proof lies in the European market's preponderant position (between 67\% and 93\%) in the geographic spread of European firms' commercial revenues (see Table 2.3). Only DaimlerChrysler is an exception to this rule, with the European market now representing only about $33 \%$ of the firm's commercial revenues $(67 \%$ before the acquisition of Chrysler). Note that Europe's share has been shrinking for most firms (notably Volvo), something that is explained by the decision to increase sales in the world's other regions in order to benefit from growth in the new markets and to reduce dependency on Europe. In this respect, European firms have been pursuing highly differentiated commercial diversification strategies, as shown in Table 2.4.

Although a geographic breakdown does not enable any distinction to be made between the three poles of the Triad and the developing countries, note

Table 2.3 Europe's share (including the country of origin) in European firms' commercial revenue, as percentage of world's sales

\begin{tabular}{lcccccccc}
\hline Years & BMW & DaimlerChrysler & $\begin{array}{c}\text { Fiat } \\
\text { Group }\end{array}$ & PSA & Renault & Scania & VW & Volvo \\
\hline $1990-9$ & n.a. & 66.9 & 79.8 & 92.8 & 86.0 & 71.1 & 76.8 & 60.0 \\
$1995-9$ & 67.6 & 35.4 & 76.0 & 93.4 & 85.0 & 74.8 & 74.2 & 58.0 \\
1999 & 64.4 & 33.3 & 79.5 & 93.7 & 83.2 & 82.9 & 74.0 & 55.2 \\
\hline
\end{tabular}

Note: For DaimlerChrysler, the periods are 1990-6, 1997-9 and 1999. For Volvo, 1991-9, with passenger cars being excluded; n.a. = not available.

Source: Our own calculations with data from the firms' financial reports.

Table 2.4 Breakdown of European firms' commercial revenue outside Europe, 1995-9, as percentage of world sales

\begin{tabular}{|c|c|c|c|c|c|c|c|c|}
\hline \multirow{2}{*}{$\begin{array}{l}\text { Regions } \\
\text { North America }\end{array}$} & \multicolumn{2}{|c|}{ BMW DaimlerChrysler } & \multirow{2}{*}{$\begin{array}{c}\begin{array}{c}\text { Fiat } \\
\text { Group }\end{array} \\
6.8\end{array}$} & \multicolumn{5}{|c|}{ PSA Renault Scania VW Volvo } \\
\hline & 18.0 & 49.9 & & n.a. & 10.0 & n.a. & 10.4 & 27.3 \\
\hline South America & n.a. & 8.5 & 11.8 & n.a. & n.a. & 15.7 & 9.8 & 6.0 \\
\hline Asia/Pacific & 9.2 & 3.7 & n.a. & n.a. & 3.5 & 4.5 & 4.1 & 5.9 \\
\hline
\end{tabular}

Note: For DaimlerChrysler, the period is 1997-9; n.a. = not available. The total is not equal to $100 \%$ because of other countries not included in the above table.

Source: Our own calculations with data from the firms' financial reports. 
that only Volvo and the three German firms have been able to build a significant commercial presence in the Triad's second pole; that is, in North America. ${ }^{19}$ In this respect, the Japanese firms are far ahead. Fiat is an interesting example inasmuch as it owes its North American presence not to its automobile assembly activities in the strictest sense of the term but to its other group subsidiaries. Another special case is Daimler-Benz, which between 1990 and 1997 made nearly $23 \%$ of its world sales in North America, and more than doubled its sales in that continent after the creation of DaimlerChrysler. As is the case for American firms, European firms' commercial revenues in Asia (and a fortiori in Japan) remain less than $5 \%$ of their total sales, apart from premium brands such as BMW (9.2\%) and Mercedes-Benz (9.7\% over 1990-6).

Outside the Triad, European firms differ from American and Japanese firms because of their significant presence in South America, particularly in Mercosur. Fiat and Scania are the most active in this market. Mercosur represents an even greater percentage of Fiat's automobile activities, accounting for $20.7 \%$ of Fiat Auto's total world sales in 1995-8. South America provides the most accessible rapid development zone for those European firms seeking to reduce their dependency on the European market. PSA, which set itself an objective of making $25 \%$ of its total sales outside Europe by 2003, has reinforced its presence in Mercosur. Renault has announced a target of $40 \%$ of sales outside Europe by 2010 , with Mercosur planned to become the firm's second largest market (after Europe) in 2005.

We should emphasize that European firms' generally high level of internationalization in fact hides a major regional phenomenon. Like GM and Ford, most European firms make around $25 \%$ of total sales outside of their region of origin (Europe or North America) because of a strong presence in a second continent. However, they are often geographically diversified to a greater extent than their American counterparts, possessing a significant presence (around 10\%) in a third zone (South America or Asia).

Finally, most Japanese firms are even more geographically diversified, although the proportion of commercial revenues realized abroad is on average lower than for European firms (see Table 2.5). Japanese firms are noteworthy because they have the highest commercial presence in a second Triad pole (North America) and a significant commercial presence in a third pole (Europe). With the exception of Mitsubishi and Suzuki, all make at least a third of their total sales in North America. For Honda this percentage is $50 \%$, higher even than its sales in Japan - the only example of such a percentage split, apart from DaimlerChrysler, which is a less straightforward situation.

The big Japanese firms realize at least $10 \%$ of their total sales in Europe. It is also the case of Toyota following its establishment of production facilities in France. As a result of this commercial diversification, Japanese firms would appear to be the least dependent on their region of origin. Although available statistics remain somewhat imprecise, we know that Suzuki alone (mainly because of its successes in Japan and India in the mini-car niche) 
Table 2.5 Breakdown of Japanese firms' commercial revenues, 1997-9, as percentage of world sales

\begin{tabular}{lcccccccc}
\hline Regions & \multicolumn{2}{l}{ Honda Isuzu } & Mazda & Mitsubishi & Nissan & Subaru & Suzuki & Toyota \\
\hline North America & 50.1 & 35.4 & 31.9 & 21.9 & 33.3 & 43.6 & 12.6 & 36.6 \\
Europe & 12.0 & n.a. & 17.5 & 14.3 & 15.4 & 7.5 & 21.0 & 9.0 \\
Asia/Pacific & [28.38] 46.8 & {$[37.51]$} & 51.1 & {$[41.49]$} & {$[44.49]$} & 59.9 & {$[42.54$} \\
& & & & & & & & \\
\hline
\end{tabular}

Notes: n.a. $=$ not available. Japan is included in the Asia/Pacific zone. The numbers in brackets are estimations based on the following principles: the minimum corresponds to Japan's share, the maximum to Japan's share + the share of countries from the rest of the world (Asia, South America, Pacific, etc.).

Source: Our own calculations from the firms' financial reports.

depends on the Asian market for around $60 \%$ of its business, a figure that is nevertheless lower than the region of origin's significance for American or European firms' commercial revenues.

In conclusion, the findings confirm that the automobile industry is not entirely globalized, since no firm sells a balanced proportion of its total output in all three poles of the Triad. However, if firms do reach the targets they have set, within ten years there should be an increase in the percentage of commercial revenues realized outside their region of origin. ${ }^{20}$ American and European firms seek to reinforce their commercial presence in Asia, and specifically in Japan, ${ }^{21}$ while Japanese firms are trying to develop sales in Europe. As competition is particularly strong in the three poles of the Triad, it is likely that only a few firms will be able to make a significant proportion (say, 20\%) of total sales in each of the three continents. Hence their strong interest in emerging countries, where the potential for market growth makes it easier for a firm to gain a foothold.

\section{The productive internationalization of the automobile industry has increased, but still remains limited in scope}

Productive internationalization can first of all be analysed in physical terms by measuring the percentage of total output realized outside the country of origin, and then outside the region of origin. These first two findings will be supplemented by a value analysis that compares total sales by zone of commerce with turnover by production zone in order to evaluate the respective importance and role of commercial and productive internationalization.

Automobile firms' production outside their country of origin rose sharply during the 1990s. From an average of $27 \%$ in $1990-4$, it reached $40.6 \%$ in $1995-9 .{ }^{22}$ As such, the automobile industry has not been globalized from a production perspective, with the national framework continuing to exert a crucial influence on productive organization, employment relationships and relations with the state. But even though productive internationalization continues to rise at the same pace, most firms will be producing at least 


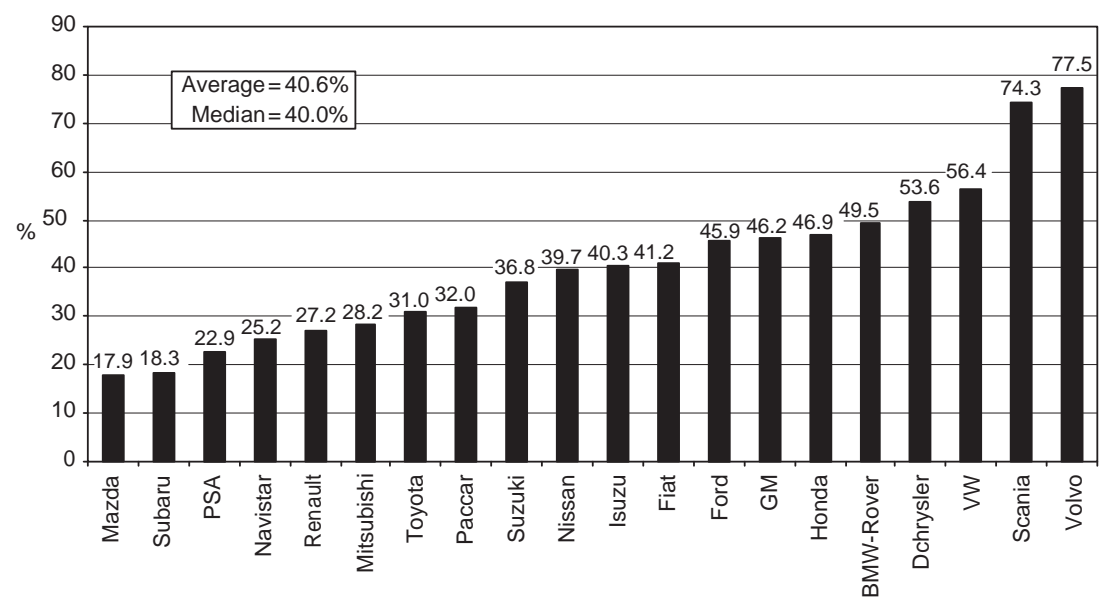

Figure 2.1 Production share outside country of origin, 1995-9

Source: Own calculations from data of CCFA.

$50 \%$ of their total output overseas over the course of the first decade of the twenty-first century. Figure 2.1 shows how firms were positioned in 1995-9, with $50 \%$ of all firms realizing outside their country of origin an output that was superior or equal to $40 \%$ of their world production. Only five out of twenty firms, all European, featured an overseas production superior or equal to $50 \%$. This category includes Volvo and Scania, who were forced to behave in this manner by the narrowness of their country of origin. There were also two firms whose presence in this leading group can be explained by their acquisition of a foreign competitor: BMW, which bought Rover in 1994 and resold it in 2000;23 and DaimlerChrysler, after Daimler-Benz bought Chrysler in 1997. With the exception of these special cases, VW appears to be the only integrated generalist firm whose production outside its country of origin (56\%) is ten points higher than Honda, Ford and GM. This vision of an already significant yet rapidly rising productive internationalization should be fine-tuned through the incorporation of a regional dimension. As shown by Figure 2.2, which covers 1996-9, a much lower percentage of total production is being realized outside firms' region of origin. ${ }^{24}$ This indicates that firms are more regionalized than globalized; $50 \%$ of all firms feature production outside their region of origin that is superior or equal to $19.6 \%$, with average extra-regional output reaching $20.7 \%$, a very low figure. Only DaimlerChrysler (54\%) and Honda (43\%) distinguish themselves from the pack with outcomes that are more than twice the overall average. Apart from the special case of DaimlerChrysler, Honda has gone the furthest towards productive internationalization. However, Honda's 


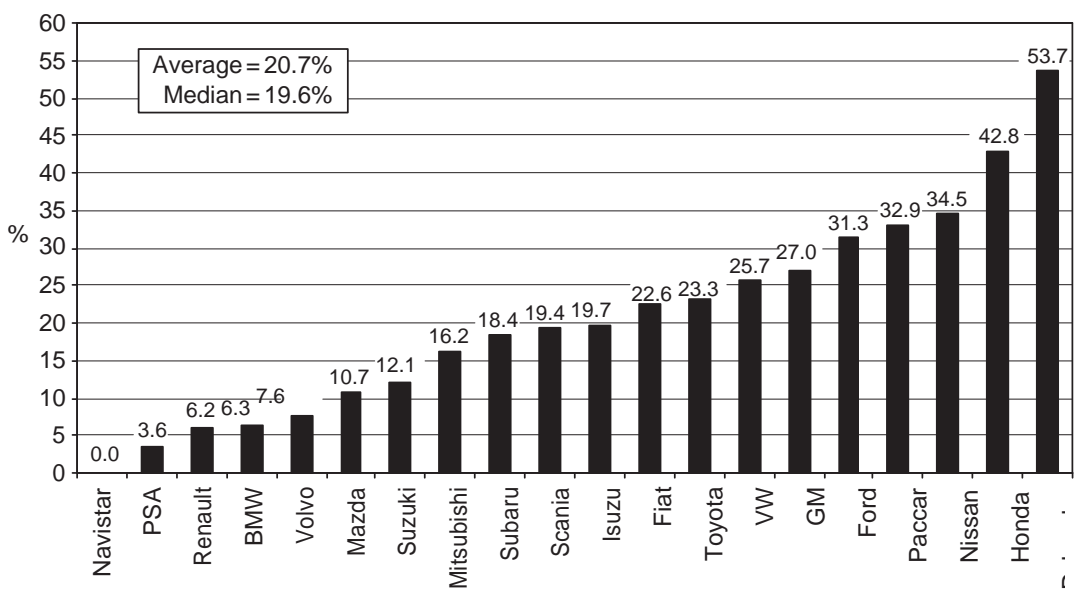

Figure 2.2 Production share outside region of origin, 1996-9

Source: Own calculations with data from the CCFA.

extra-regional production is spread very unevenly: $37.6 \%$ in NAFTA versus only $4.8 \%$ in Europe. Nissan, which manufactures $34.5 \%$ of its output outside Asia/Pacific/Africa, features a more balanced spread of productive facilities: $20.6 \%$ in NAFTA and $13.7 \%$ in Europe.

American firms' extra-regional production is just as unbalanced and concentrated in Europe: $25.2 \%$ of GM's output, out of an extra-regional production total of $27 \%$, takes place in 'Europe and Turkey'. ${ }^{25}$ For Ford, the percentages are $25.2 \%$ out of $31.3 \%$ (Paccar's extra-regional production being entirely located in 'Europe and Turkey'). Among the European firms, only VW (25.7\%) and Fiat (22.6\%) do any significant manufacturing outside Europe, mostly in South America. VW manufactures 12.8\% of its world output in South America, while also producing in NAFTA $(6.9 \%)$ and in Asia/Pacific/Africa (5.9\%). Fiat is very dependent on South America, where it realizes $20.5 \%$ of its world output. Apart from Scania, the remaining European firms manufacture less than $10 \%$ outside Europe, although it should be said that numbers have been rising.

Apart from Toyota, most Japanese firms are characterized by extraregional production that is inferior or equal to the overall average (20.7\%). Excluding Suzuki, they all have in common the fact that basically they carry out no manufacturing in South America, and produce less than $6 \%$ in Europe. Japanese NAFTA zone output ranges from 11\% (Mazda, Mitsubishi) to $19 \%$ (Toyota, Isuzu and Subaru). Production in the 'Asia/Pacific/Africa' zone can be quite significant (Mitsubishi 15\%, Isuzu $22 \%$, Suzuki 28\%).

In conclusion, we are a long way from the often conjectured generalization that global firms have been carrying out manufacturing operations in 
all three poles of the Triad. In its current shape, international production focuses on the region of origin. At best, foreign plants have been built in a second pole of the Triad for American and Japanese firms, and some European firms; and in emerging countries for other European firms. If this concentration trend continues through the first decade of the twenty-first century, that is, if it turns out to be a durable phenomenon, we might witness the creation of firms that do manufacture in all three poles of the Triad. ${ }^{26}$ However, given the difficulty of transforming such groupings into profitably integrated firms, it is much more likely that productive internationalization will follow a slower and more modest path involving a steady increase in existing firms' production capacities outside their continent of origin.

We have seen that productive internationalization is already significant outside firms' countries of origin, but that it remains limited to the regional framework. This in turn provides a glimpse of an incipient regional division of labour within which subsidiaries from the country of origin can play a key role as an export base destined to supplement the regional subsidiary network. A value analysis that distinguishes between commercial revenues and production revenues will help us to delve further into this phenomenon.

More specifically, the difference between commercial and production revenues, as presented in Table 2.2, helps us to calculate how important exports are to each firm's total sales. ${ }^{27}$ When overseas sales are greater than overseas production (the sales realized by each production facility), exports coming out of a firm's country of origin automatically explains the difference.

We can then break these export flows down by main geographic zones to evaluate the regional phenomenon's significance. The results are combined in Table 2.6, which presents a geographical breakdown of exportable surpluses by firm and by era. ${ }^{28}$ Note that the country of origin's subsidiaries almost always show an exportable surplus that can be added to the local production by foreign subsidiaries, which are generally net importers. With respect to European firms, note also that $\mathrm{VW}$ and Fiat, the most internationalized companies in terms of the number of vehicles produced abroad, nevertheless generate much lower revenues per overseas production facilities $(35.6 \%$ and $38.4 \%$, respectively; see Table 2.2). They must therefore be exporting a high percentage of goods and services $(27.3 \%$ and $24.2 \%$ respectively; see Table 2.6). It would appear that overseas investments generate a flow of exports from a country of origin. We infer from this that overseas production is marked by a low level of local content. German and Italian subsidiaries satisfy demand from their respective countries but also serve as an export base, essentially for exports towards other European countries (and to much less an extent, to subsidiaries on other continents where firms have established operations).

In percentage terms, French firms achieve much higher revenues from overseas production facilities ( $45.6 \%$ for Renault, $50.1 \%$ for PSA). Above all, they are twice as high as one could expect, given the actual foreign manufacturing in which they engage (measured in physical terms). In this sense, Renault and 
Table 2.6 Breakdown of exports from country of origin destined for foreign subsidiaries, as percentage of commercial revenue

Firms

Exports (+) and imports (-)

\begin{tabular}{|c|c|c|c|}
\hline $\begin{array}{l}\text { Country } \\
\text { of origin }\end{array}$ & Europe & $\begin{array}{c}\text { North } \\
\text { America }\end{array}$ & $\begin{array}{l}\text { Other } \\
\text { countries }\end{array}$ \\
\hline
\end{tabular}

\begin{tabular}{lrrrrr}
\hline VW (95-97) & 27.3 & -19.0 & -4.8 & -3.5 & -27.3 \\
Fiat (95-99) & 24.2 & -18.7 & n.a. & -5.5 & -24.2 \\
PSA (95-99) & 10.6 & -4.9 & n.a. & -5.7 & -10.6 \\
Renault (95-98) & 11.3 & -5.5 & n.a. & -5.8 & -11.3 \\
Honda (97-99) & 3.8 & -0.3 & 0.4 & -3.8 & -3.8 \\
Nissan (97-99) & 4.0 & -0.2 & 2.5 & -6.4 & -4.1 \\
Toyota (97-99) & 8.6 & -0.4 & -2.5 & -5.5 & -8.4 \\
Isuzu (97-99) & 22.6 & n.a. & -0.8 & -21.9 & -22.7 \\
Mazda (97-99) & 20.5 & -7.3 & -3.7 & -9.4 & -20.4 \\
Mitsubishi (97-99) & 17.5 & -3.9 & -2.4 & -11.2 & -17.5 \\
Subaru (97-99) & 15.0 & -7.5 & -3.2 & -4.3 & -15.0 \\
Suzuki (98-99) & 21.2 & -6.5 & n.a. & -14.7 & -21.2 \\
\hline
\end{tabular}

Notes: For each geographical zone, the difference between productive revenues and commercial revenues has been calculated. Whenever data are not available for individual countries (n.a.), it is included in the category 'other countries'. Fiat is the Fiat Group.

Source: Our own calculations from the firms' financial reports.

PSA are more internationalized than VW and Fiat. Unsurprisingly, their exportable surplus is two times lower $(10.6 \%$ for PSA and $11.3 \%$ for Renault). It is also relatively equally balanced between their other European subsidiaries and the units they run in other continents (see Table 2.6). French firms' foreign subsidiaries are therefore much less dependent on the goods and services that their parent company subsidiaries export than is the case for VW and Fiat. ${ }^{29}$

The Japanese firms are divided into two groups. On one hand there is Honda and Nissan, whose revenues per production facility are very similar to their overseas commercial revenues (see Table 2.2). This explains why exports from Japanese subsidiaries only represent around $4 \%$, the lowest figure in our sample - a confirmation that the two firms have been able to set up autonomous productive bases outside their region of origin. Honda and Nissan's Japanese exports are for the most part destined for the 'other countries' (including Asia) that also receive goods and services from North America (this latter zone features a slight trade surplus, whereas trade with Europe is more or less in equilibrium). The other firms (Isuzu, Mazda, Mitsubishi, Subaru, Suzuki) realize overseas sales of below $40 \%$ (see Table 2.2) and depend more traditionally on their Japanese subsidiaries for exports to the world's other regions (see Table 2.6). Such exports are for the most part to Asia (that is, the 'other countries' category) and to a lesser extent to Europe, where this 
sub-set is still running a small and sometimes non-existent productive base. Toyota is in an intermediate position, as it only exports $8.6 \%$ of the total revenues of its Japanese subsidiaries in 'other countries' and North America.

In sum, these figures confirm that commercial internationalization no longer plays anything more than a minor role for the big firms, even if it still plays a significant role for the 'small' ones. It complements productive internationalization in the region of origin, and to a lesser extent supports firms' presence in other continents.

Finally, this overview of corporate internationalization confirms that most firms remain rooted in the specific country that is crucial to their business. Although all firms have developed a commercial and productive presence in their region of origin, this is only really crucial for European firms and for certain Japanese companies (Isuzu, Mitsubishi, Suzuki). The drive to establish operations in a second region can vary greatly, accounting on average for anything between a fifth and a third of a firm's total activities (with very few exceptions; that is, Honda and DaimlerChrysler). The result is that firms' global profits continue to be highly influenced by their national context, with the international environment allowing firms to smooth out fluctuations in their national markets; and to create additional profit opportunities. This is what we shall be analysing in detail in the next section.

\section{Internationalization, a source of profit and loss}

International expansion is usually viewed as something that is indispensable for a firm's survival. Yet international activities are not always profitable, and can even be a source of substantial losses. Conversely, foreign profits can sometimes offset the losses made in a firm's country of origin, particularly when the economic situation is desynchronized from one continent to the next. In order to verify foreign profits' contribution to total profits, we have defined a contribution indicator based on the total profits realized by domestic and foreign activities. This is expressed in percentages (see the methodological appendix on page 46). ${ }^{30}$

\section{Changes in American firms' international profits}

Ford and GM were setting up overseas facilities from the early twentieth century onwards, first in Europe and then throughout the world. The data we have been able to gather begins after the Second World War and covers the two firms' net world profits (see Figures 2.3 and 2.4). We can see that, for GM and Ford, international profits made a positive but small contribution to world profits during the post-war boom years and up to the early 1970s. Most profits were realized from domestic activities, representing an average of $80 \%$ of the two firms' world profits - foreign activities thus only contributing an average of $20 \%$. Then, starting with the first generalized world recession (1974-5), the two firms' paths began to diverge. 

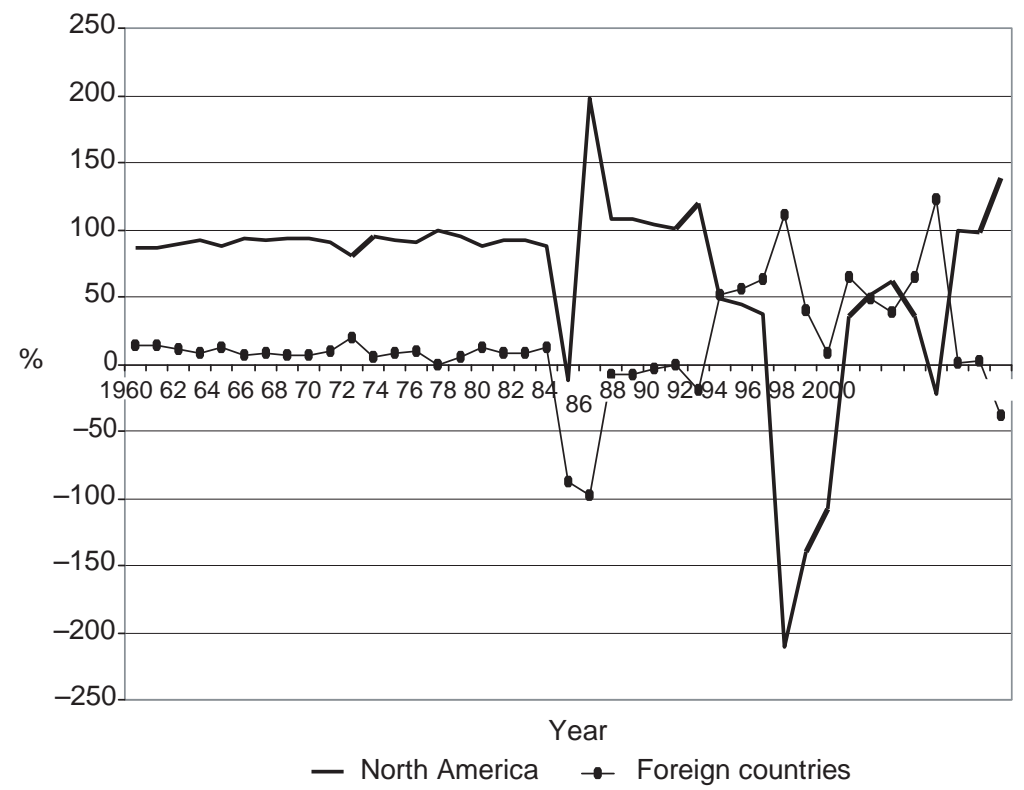

Figure 2.3 North America's and foreign countries' contribution to GM's global net profit, 1960-2000

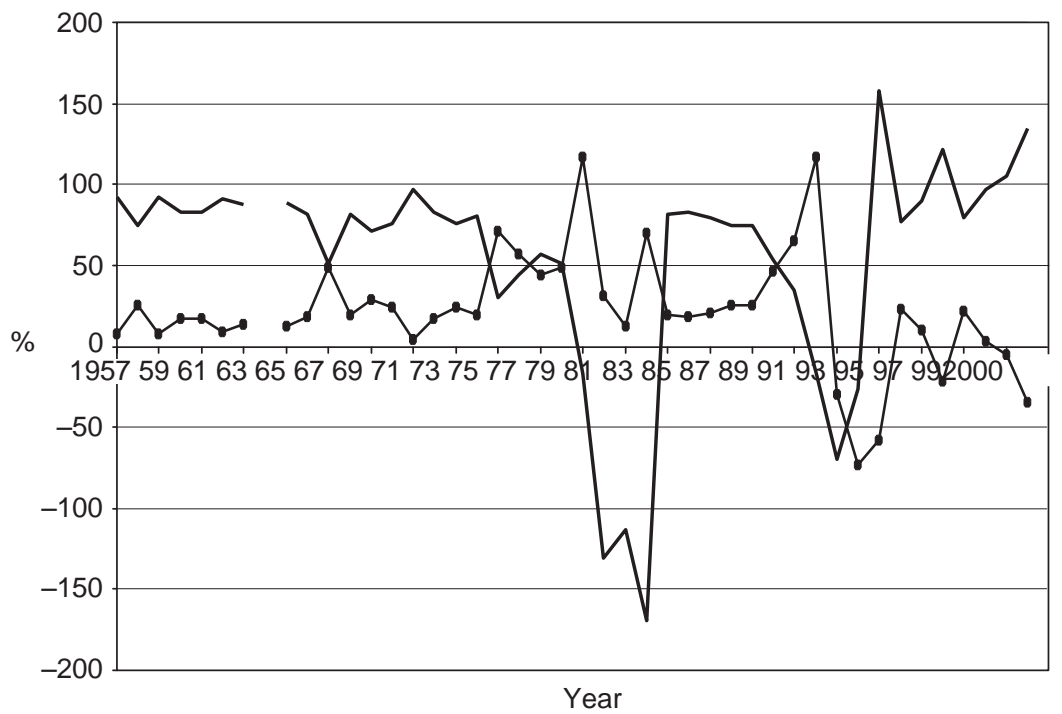

- North America $\rightarrow$ - Foreign countries

Figure 2.4 North America's and foreign countries' contribution to Ford's global net profit, 1957-2000 
Ford was shaken deeply by this first recession in its domestic market, but was able to offset lower profits in North America with profits drawn from its foreign activities, which at the time represented more than half of its world profits. On the other hand, during the second global recession (1979-81), North America's preponderance in the firm's total revenues was reflected in Ford's problems in finding sufficient foreign profits (which were also in decline) to offset the losses made by its American subsidiaries. The end result was that it was no longer possible to avoid an overall loss. Renewed growth in North America from 1983 onwards re-established the hierarchy that had characterized the 1950s and 1960s (with around $80 \%$ of profits being made in North America and $20 \%$ overseas), but this was temporary. During the third global recession (1991-2 in North America; 1992-3 in Europe) overseas subsidiaries made substantial losses, exacerbating losses in North America. Subsequently, and during the entire 1990s, profits from abroad could no longer offer any significant and/or durable contribution to world profits, nearly all of which would come from North America. This change can be explained by the long duration of North American growth (March 1992- December 2000), but also by the fact that Ford was unable to adapt to a period of slow growth in Europe (1990-7). Yet it was in this latter continent that most of the firm's overseas profits were being determined, Europe accounting for 24\% of Ford's total sales. From 1990 to 2000, European subsidiaries spent five years in the red, totalling US\$3.5 billion of losses - against six years in the black, totalling US\$639 million.

Ford's foreign profits outside Europe were nothing to write home about.

The firm had been making significant profits in South America in the late 1970s, when the Brazilian market was nearing its first apex. It then lost money throughout the 'lost decade' of the 1980s. Later, Ford did not really derive maximum benefits from the rise of Mercosur (1990-7), and ran lossmaking operations from 1995 onwards. It reached a nadir of US\$642 million in 1996, with the firm subsequently having to take the full brunt of the 1998-9 Mercosur crisis. In comparison, Asian subsidiaries turned out to be much more profitable and were hardly affected by the Asian crisis (1997 a loss of US $\$ 33$ billion; return to profit in 1998). But Asian profits did not in general suffice to offset South American losses. From 1990 to 2000, the whole of South America and Asia/Pacific/Africa recorded three years in the black, totalling US\$116 million, and eight years in the red, totalling US\$1.6 billion. Instead of offsetting European losses, losses in the developing countries compounded them.

Above and beyond temporary vicissitudes, there is also a structural problem. It is surprising that the main and almost sole profit source of the world's second leading automaker, whose internationalization goes back a long way, is its domestic market.

GM has to a certain extent had the opposite experience. Its North American subsidiaries overcame the second global recession better than did 
its foreign subsidiaries. In 1981, GM's North American contribution to world profits was about $200 \%$, more than offsetting the negative contribution of its loss-making overseas operations (around 100\%). This allowed GM to record an overall profit. During the 1980s, earnings from foreign subsidiaries (which initially were mediocre) improved up to 1987, first reaching and then surpassing $50 \%$ of world profits. At the same time, profits from North American subsidiaries developed a downward trend. Profits from foreign subsidiaries helped GM partially to absorb the shock of the 1992 recession in North America, accounting for $100 \%$ of world profits in 1997 (before collapsing in 1998-9). As in the case of Ford, these changes were mainly a reflection of the European subsidiaries' behaviour. It is specifically because of European losses that overseas activities made an overall negative contribution to GM's world profits in 1979-82, and it is thanks to Europe's positive contribution that GM was able to limit the impact of American losses in the early 1990s. South America and Asia/Pacific/Africa made a marginal but almost always positive contribution during the 1970s and 1980s. South America's contribution rose after 1992, with a jump of more than $150 \%$ in 1997, a year when South America was the only region where GM recorded net profits. This shows that GM (unlike Ford) was able to take full advantage of South America's return to growth after the 'lost decade' of the 1980s. However, the 1997 Asian crisis, which led to this region making a negative contribution equivalent to $50 \%$ of world profits, soon had a knock-on effect in South America, whose contribution became negative in 1998. The speed with which this crisis spread, characteristic of financial globalization, demonstrates the fragility of the profit opportunities that emerging countries offer to multinational firms. Even more surprising is Europe's mediocre profit contribution. Throughout the 1990s this remained below $30 \%$, and it continued to decline in 1998, despite Europe's return to growth. This is another sign of the structural difficulty of satisfying European demand.

In sum, the results have been more positive for GM than for Ford. Foreign subsidiaries played a positive role in term of profitability during the 1980s1990s, a period of decline for GM in North America. Renewed growth in this region during the 1990s meant that US profits superseded foreign profits from 1998-9. In 1990-2000, GM accumulated around US $\$ 18$ billion of profits in North America versus nearly US $\$ 13$ billion of losses. Overseas it accumulated nearly US $\$ 14.4$ billion of profits versus US $\$ 883$ million of losses. Internationalization has indeed been very profitable.

\section{Japanese firms' international profits ${ }^{31}$}

In recent years, the Japanese economy has been characterized by the strong rise of the yen versus the dollar in 1986-7, and then, during the 1990 s, by the country's entry into a period of slow growth triggered by the 1991 bursting of the financial bubble (followed by recessions in 1993 and above all in 1998). In 1998-9, new vehicle sales in Japan fell below the 4 million unit 
threshold for the first time since 1984, and production levels dropped back to their level of the early 1980s. Against this backdrop of Japanese economic crisis, foreign markets represented a crucial source of profit.

From this perspective, Japanese automakers can be divided into two categories. On the one hand there is a sub-set with Toyota (1982-99) and Honda (1972-99), who were profitable the whole time (whether profits came from Japan or from abroad), and who were not really affected by the recent macroeconomic shocks. Suzuki is also part of this sub-set, even though its profitability is less clear-cut. Inversely, there is a sub-set with Nissan, Mitsubishi and Mazda whose internationalization strategies ended in failure (inasmuch as overseas activities almost always recorded losses that were difficult to offset with domestic profits). Subaru is in an intermediate position, having recently succeeded in rebuilding an overseas activity that had long been a loss-maker.

Toyota is a paragon of regularity (see Figure 2.5), with profits from domestic activities varying between $70 \%$ and $90 \%$ of total profits, and leaving overseas profits to make a contribution of $10 \%$ to $30 \%$. Toyota thus remains highly dependent on its country of origin in profit terms, but is one of the few firms to have a regular flow of profits from abroad. These foreign profits stem almost

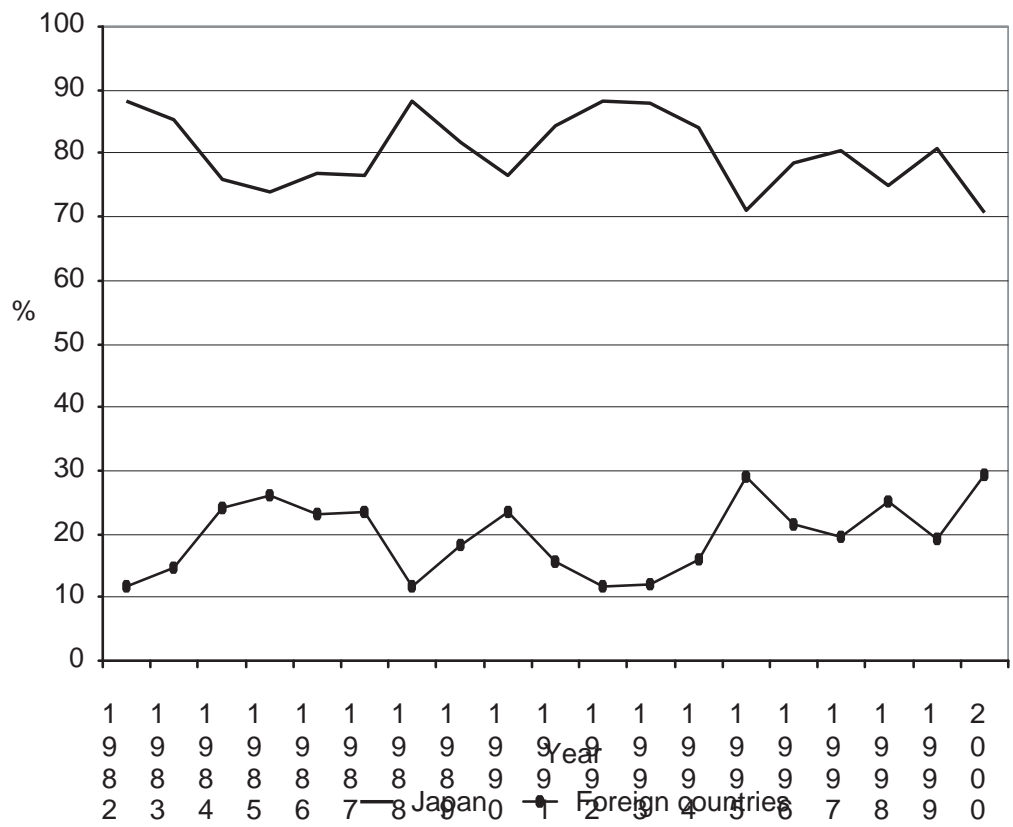

Figure 2.5 Japan's and foreign countries' contribution to Toyota's global net profit, 1982-2000 


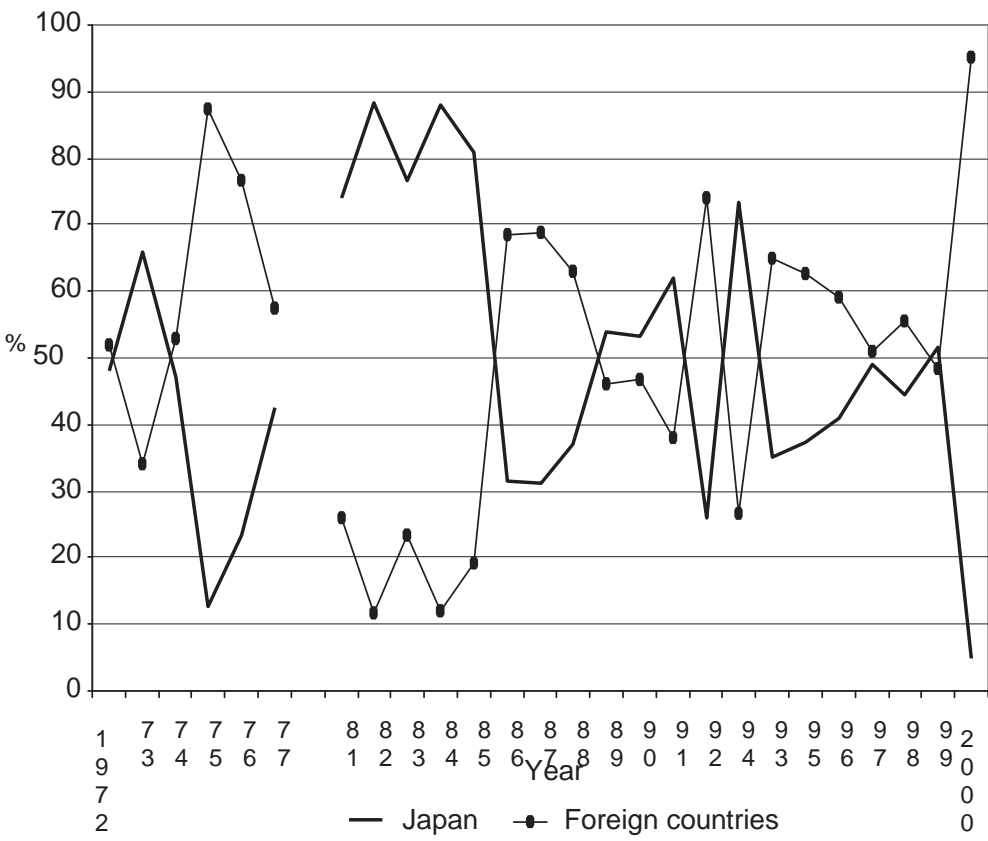

Figure 2.6 Japan's and foreign countries' contribution to Honda's global net profit, 1972-2000

entirely from North America, with Europe and 'other countries' contributing nothing at all, and sometimes even negatively. Over 1997-2000, foreign contributions to Toyota's operating profits reached $21.6 \%$, including $21.5 \%$ for North America, $-0.7 \%$ for Europe and $0.8 \%$ for the other countries.

On the other hand, Honda (see Figure 2.6) experienced a period of great instability. Apart from 1981-5, when net profits from Japan were increased by a factor of 2.4 (at the same time that foreign profits were growing slowly), net Japanese and overseas profits evolved in a similar and closely correlated manner, but with hierarchical modifications from one year to the next. ${ }^{32}$ This led to a strongly oscillating contribution to domestic and foreign profits, rotating around an average value of $53 \%$ for foreign profits against $47 \%$ for Japanese profits in 1990-9. Honda is one of the few firms where foreign profits tend to represent more than $50 \%$ of world profits. This is the highest value found in our sample, confirming the highly internationalized character of this particular firm. With respect to operating profits, foreign profits accounted for as much as $60 \%$ of world profits on average in 1994-2000, and even as high as $63 \%$ in 1997-2000, because of substantial profits in North America (where Honda makes $50 \%$ of its total sales). North America made a contribution of 
$57.5 \%$ against $8 \%$ for 'other countries', and there was a loss of $-2.3 \%$ in Europe, where the euro's weakness against the pound sterling, Japanese yen and US dollar weighed heavily on profitability. According to Honda's managers, the unfavourable impact of the euro's weakness should be offset in the future by internal productive flexibility (known as the 'takai' system) in factories in Great Britain, making it possible to manufacture different models using a single production line..$^{33}$ Instead of making a small passenger car aimed at the Continental European market where profit margins that were at best mediocre have been wiped out by the pound sterling's strength against the euro, the British subsidiary might choose to manufacture SUV's with their higher profit margins, and then to export them to the United States where there is strong demand (the dollar also being strong against the pound). Room to manoeuvre is limited, however, and Honda was unable to avoid losing money in Europe in 2000.

These European losses are going to weigh more and more heavily on profitability since the slowdown in North American growth means that profits in this latter region will no longer be enough to offset deficits elsewhere. Honda's extreme dependency on North America might in fact turn into a weakness.

Suzuki (see Figure 2.7) is characterized by a successful internationalization strategy, with the exception of two interludes: 1982, when heavy foreign losses were offset by higher profits in Japan; and then briefly in 1988-9, when overseas activities made a negative contribution to profits. All in all, foreign profits contributed positively and regularly to world profits, reaching $22 \%$ on average between 1983-9, and $60 \%$ over 1990-9 (this being the record among Japanese automakers). In terms of operating profits, the foreign contribution was more modest (16.7\% over 1997-9) but more geographically diversified, with $9.7 \%$ emanating from Europe and 7\% from North America and Asia. The other Japanese automakers are characterized by the mediocre contributions of foreign profits, and even by the magnitude of overseas losses.

Subaru (see Figure 2.8) recorded negative contributions from net overseas profits up to 1995. This is mainly because of an inappropriate product offer in the United States combined with a rising yen. ${ }^{34}$ Foreign losses were difficult to offset, with (lower) profits in Japan, especially during the domestic crisis of the early 1990s. As a result, Subaru recorded a net world loss over the period 1987-94. It was finally able to recover, with overseas profits making a contribution of $40 \%$ (and national profits a contribution of $60 \%$ ) over the period 1995-9. Subaru was not affected by the Asian crisis of 1997-8, as Asia accounted for only a small percentage of its sales. More surprising is the fact that it was not harmed by the Japanese recession of 1998. A geographical breakdown of the firm's operating profits again highlights Japanese firms' significant dependency on the North American market for foreign profits: over 1997-9, North America's contribution was $29.5 \%$ versus a total foreign contribution to world profits of $30.5 \%$ (Europe and the rest of the world thus representing only $1 \%$ ). 


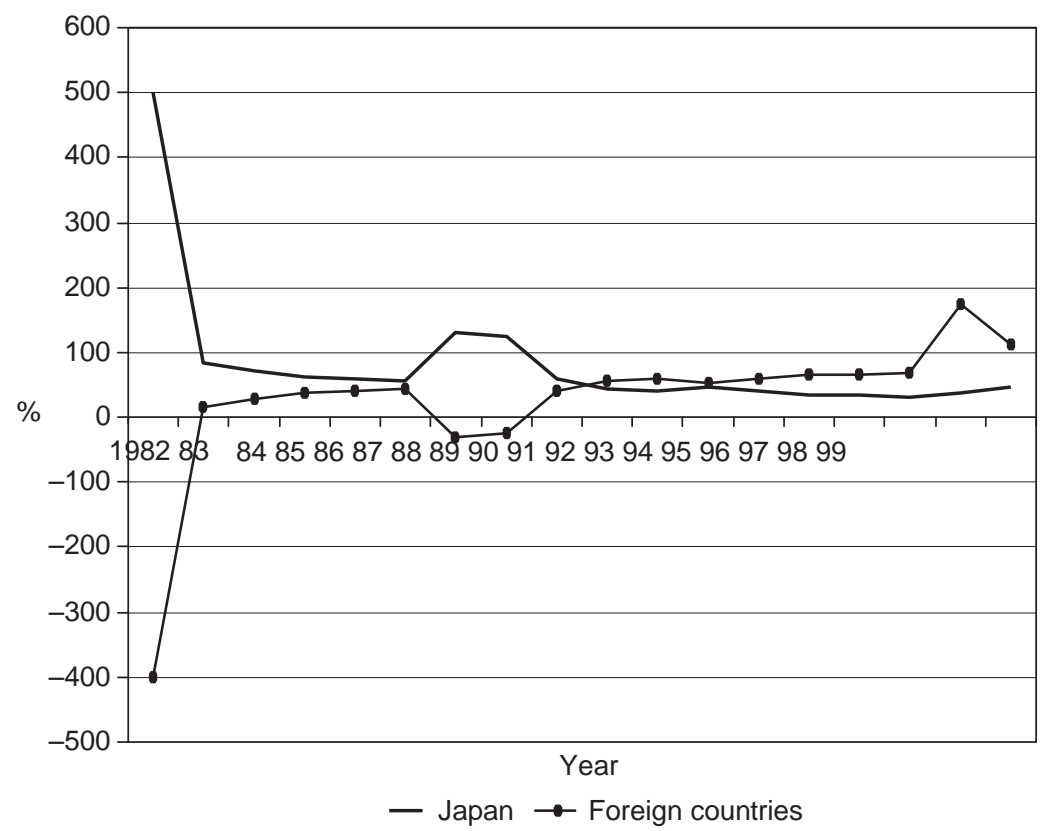

Figure 2.7 Japan's and foreign countries' contribution to Suzuki's global net profit, 1982-99

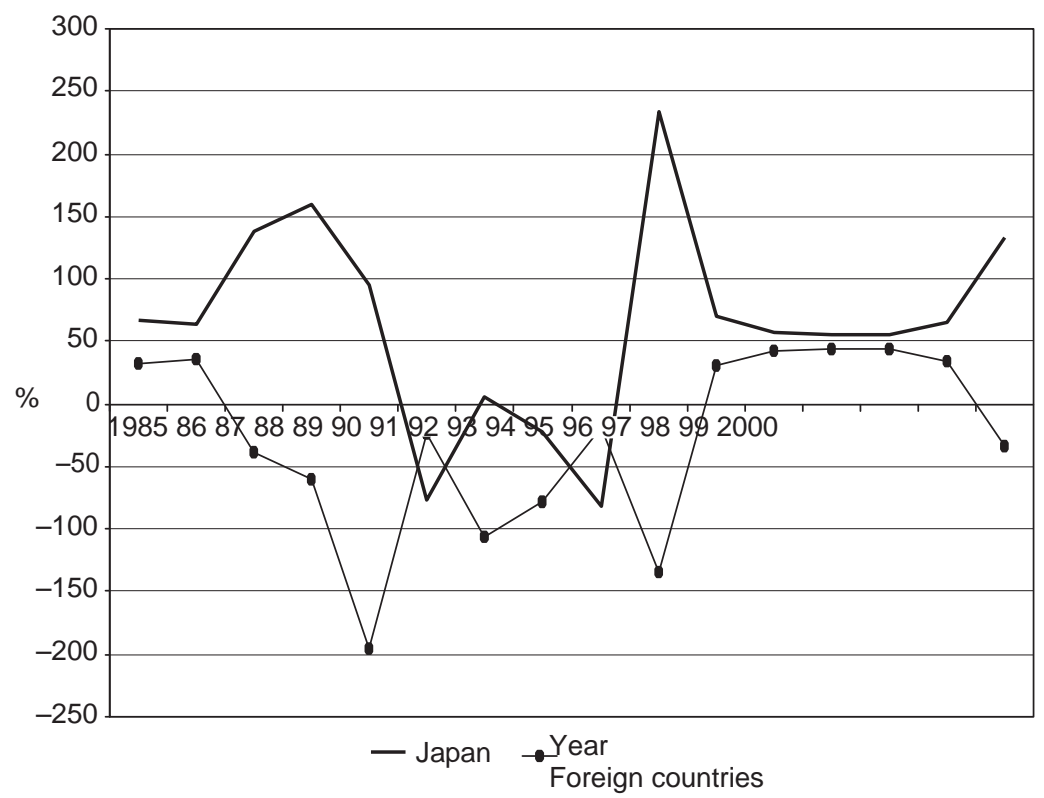

Figure 2.8 Japan's and foreign countries' contribution to Subaru's global net profit, 1985-2000 


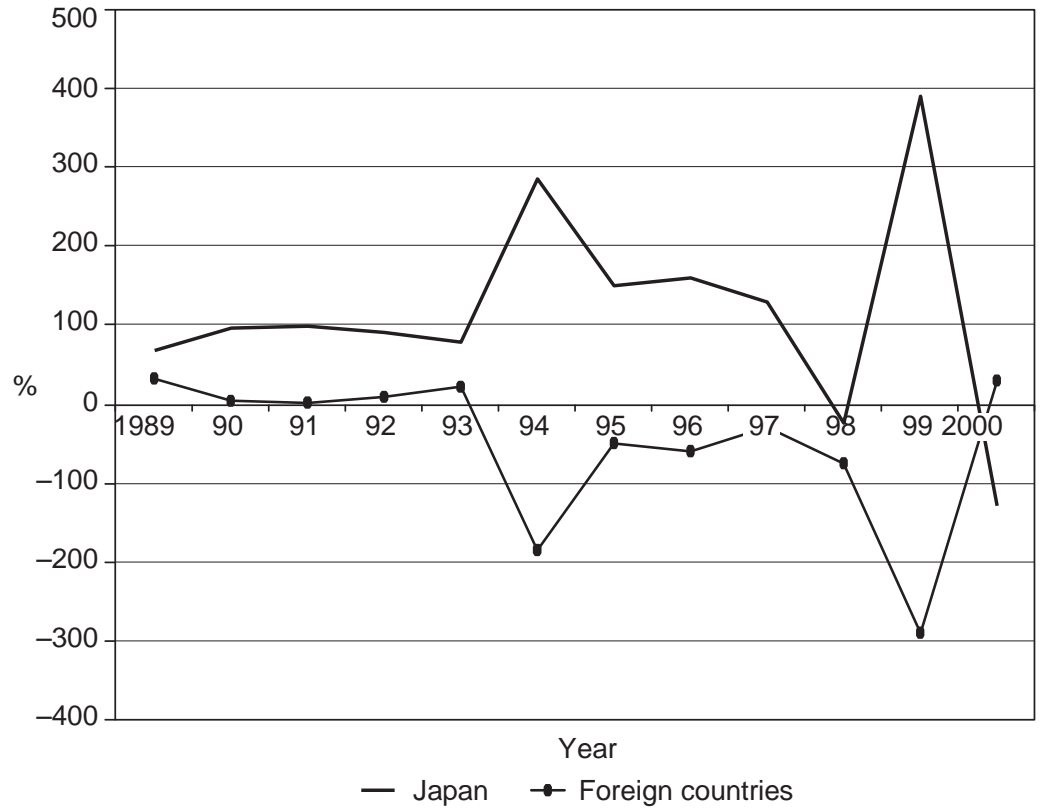

Figure 2.9 Japan's and foreign countries' contribution to Mitsubishi's global net profit, 1989-2000

The example of Mitsubishi (see Figure 2.9) is much less clear-cut. Overseas activities made only a modestly positive contribution (13\%) to the firm's net world profits in 1989-93, and then made a negative contribution $(-224.5 \%)$ in 1994-9. This could no longer be offset by the positive contribution $(+124.5 \%)$ of the net profits realized in Japan, leading to a negative world income $(-100 \%)$ over the recent period. ${ }^{35}$ Mitsubishi was hit hard by the Asian crisis ${ }^{36}$ and subsequently by the recession in Japan. Nevertheless, from 1998 onwards the firm's overseas activities were again in the black, thanks to strong growth in the North American market. The 1997-2000 geographical breakdown and operating profits shows a negative contribution from Japan $(-1858.3 \%)$ that was offset by a foreign contribution of $1958.3 \%$. However, this performance can only be explained by an excellent performance in North America (2988\%) and to a lesser extent in other countries (30.1\%), offsetting European losses ($1061.1 \%)$.

Nissan and Mazda are characterized by the almost systematically negative contribution of their foreign subsidiaries. For Nissan, the late 1970s and early 1980s were marked by foreign earnings' positive but modest contribution (12\%) to world profits (see Figure 2.10), with domestic profits accounting for between $90 \%$ and $100 \%$ of this total. The situation took a turn for 


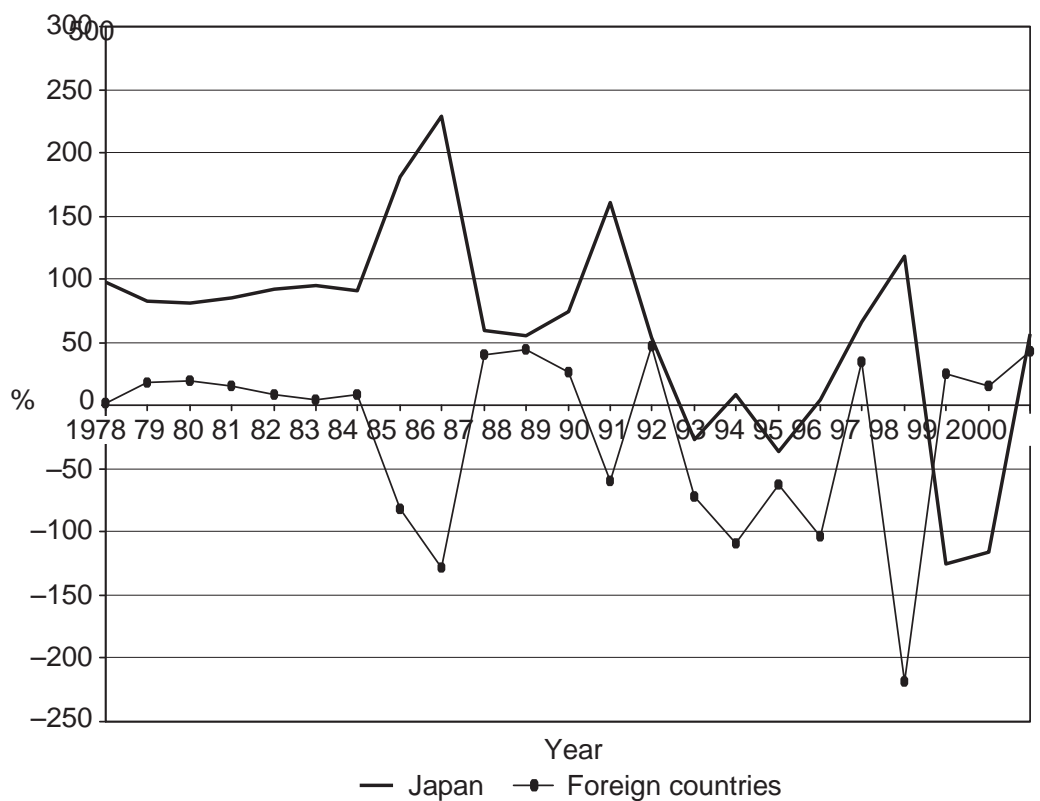

Figure 2.10 Japan's and foreign countries' contribution to Nissan's global net profit, 1978-2000

the worse in the 1980s, however, and deterioriated even further in 1992 5 , when foreign losses could no longer offset domestic activities that had been hard hit by the Japanese economic crisis. The 1997 Asian crisis had an even greater impact on Nissan's foreign activities, although Japanese operations were profitable that year. From 1998 onwards, foreign profits (largely the result of good performances in the American market) were able to offset losses in the Japanese market, albeit only partially. This improvement continued through 2000, when Nissan's Japanese activities started to make money again. A geographical breakdown of operating profits again reveals a dependency on the North American market, which made a contribution of $36.9 \%$ to Nissan's global operating profits over 1997-2000, against a total foreign contribution of $37.7 \%$. Europe was again a source of losses $(-5.6 \%)$, and the rest of the world made a modest contribution (2\%).

Mazda (see Figure 2.11) has a similar story. Overseas operations made a modest contribution to profits (12\%) between 1983 and 1989, but almost none at all in 1990-2. From 1993 onwards, contributions became increasingly negative. The domestic profits that used to offset mediocre foreign earnings could no longer stave off the losses, given that Mazda was also a victim of the Japanese economic crisis. Despite a 1995-7 rationalization-driven recovery in Japanese profits, Mazda (like Mitsubishi) was particularly hard hit 


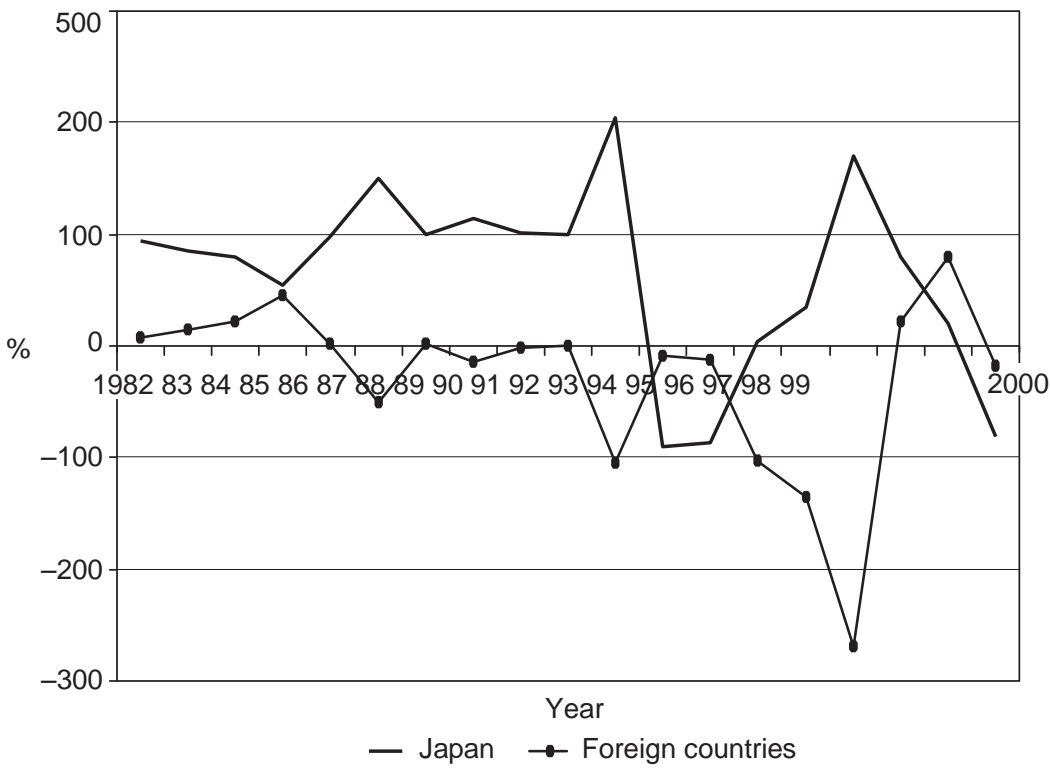

Figure 2.11 Japan's and foreign countries' contribution to Mazda's global net profit, 1982-2000

by the 1997-8 Asian crisis. In addition, Mazda is very sensitive to exchange rate fluctuations, as it depends on exports more than any other Japanese automaker (exporting more than $60 \%$ of its domestic Japanese production, compared to $50 \%$ for Toyota and $40 \%$ for Honda). It is expensive to manufacture in Japan; and the exports were being sent to countries with currencies that tend to be weak. As a result, net earnings in Japan plummeted from

+30.5 billion yen in 1998 to -127.6 billion yen in 2000 , whereas net foreign profits (which had recovered to reach 21 billion yen in 1999) fell back again to -27.6 billion yen in 2000 as a result of the rise in the yen.

The geographical breakdown of operating profits over this period (1997-2000) shows modest overseas contributions (3.1\%) thanks to Europe $(6.8 \%)$ and other countries $(1.5 \%)$, and despite losses in North America $(-5.2 \%)$. Mazda is the only Japanese firm that was unable to benefit from North America's long period of growth to offset the losses it was making in the Japanese and Asian markets.

Isuzu provides us with a final example of a relatively unsuccessful internationalization. A commercial vehicle and SUV maker, the firm suffered the full impact of the slowdown in Japanese growth, and above all of the 1998-9 recession (see Figure 2.12), during which time net losses reached 104 billion yen. Overseas subsidiaries made a negative contribution to net global profits 


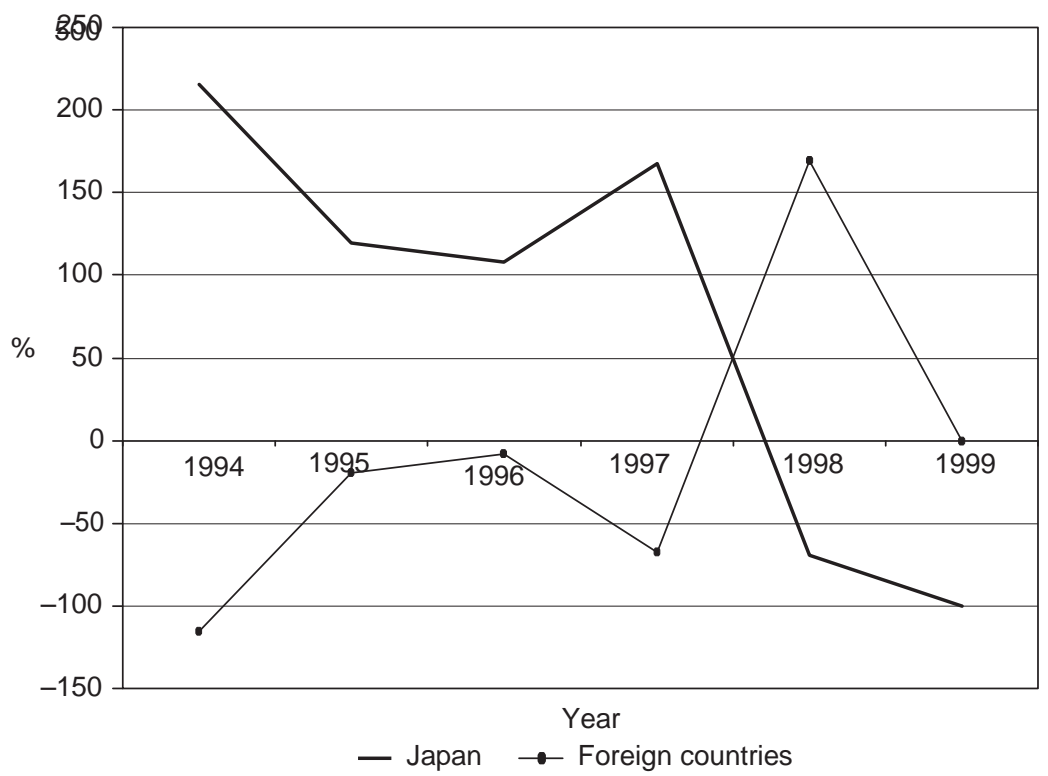

Figure 2.12 Japan's and foreign countries' contribution to Isuzu's global net profit, 1994-9

from 1994 to 1997; offset Japanese profits in 1998; and made a zero contribution in 1999. A geographical breakdown of operating profits shows that over a very short period of time (1998-9), North America and the rest of the world's contributions to foreign profits ( $5.1 \%$ and $2.7 \%$, respectively) were small and in any event insufficient to balance out Japanese losses.

\section{Changes in European firms' international profits ${ }^{37}$}

European firms can be divided into two categories. On the one hand, French firms remained highly dependent upon Europe until the late 1990s, but on the other, Fiat, VW and Scania experienced an earlier and more successful internationalization outside Europe.

For Renault, foreign profit contribution over 1982-98 was almost always positive (see Figure 2.13). From 1982 to 1989 the average contribution of foreign profits was $+59.6 \%$, while domestic French contribution was negative $(-159.6 \%)$. From 1990 to 1998 , with foreign contributions remaining at $54.8 \%$, a positive French contribution of $45.2 \%$ enhanced overall operating profits. Moreover, foreign profits played an important counter-cyclical role during periods of recession in France (1982-4 and 1992-5). However, this role was limited by the fact that Renault's foreign profits were primarily European in origin: $43.8 \%$ out of total foreign profits of $54.8 \%$ over the 


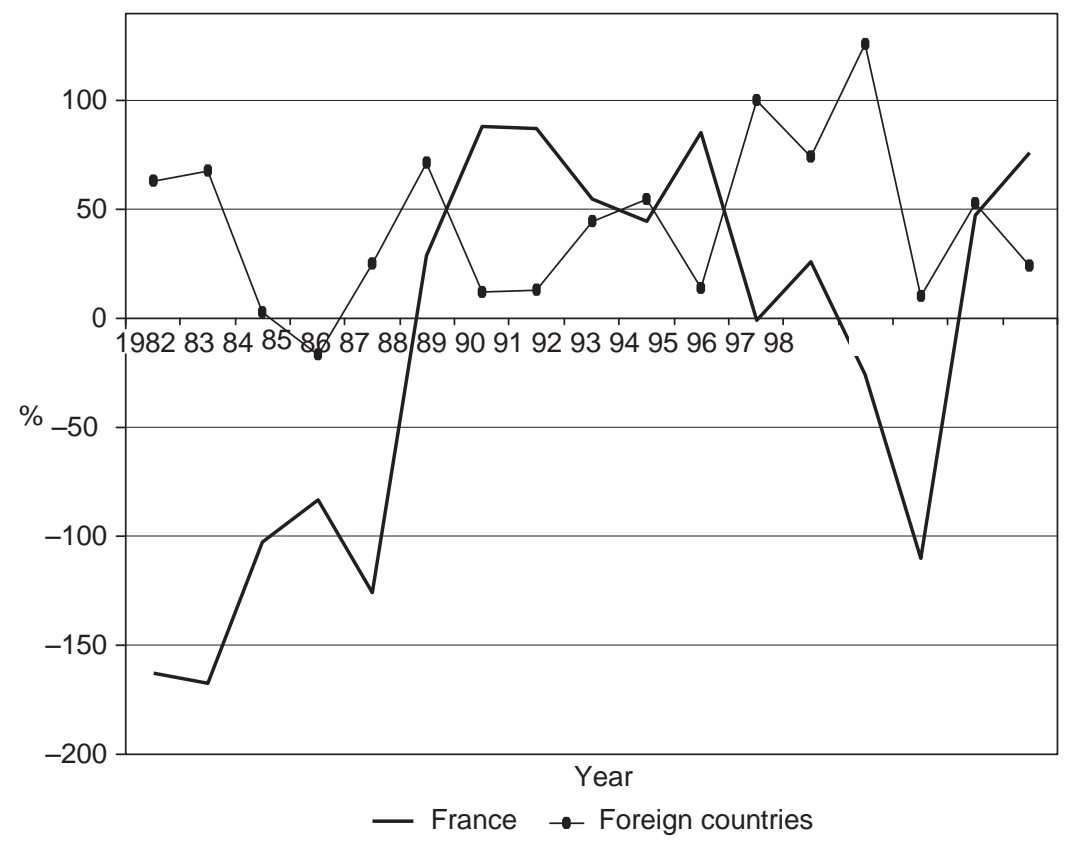

Figure France's and foreign countries' contribution to Renault's operating profit,

2.13

1982-98

period 1990-8. As such, it was the gap (or uncoupling) between French and European growth that allowed European profits to offset French losses. Finally, the overseas subsidiaries' ability to absorb potential French losses was hampered by the fact that Renault's centre of gravity was still in France at that time. From 1987 to 1998 , foreign profits remained surprisingly stable, revolving around an average value of 1.7 billion French francs, whereas French subsidiaries' profits fluctuated wildly around an average value of 2.5 billion French francs.

As was the case with Renault, after the 1979-85 crisis years, foreign profits almost always made a positive contribution to PSA's world profits. During the era of economic recovery (1985 to 1999), they accounted for $36.1 \%$ of PSA's overall earnings, against a contribution of $63.1 \%$ by French profits (much lower than for Renault). In addition, PSA's geographical diversification was limited almost entirely to Europe, meaning that foreign profits were basically tantamount to European profits (see Figure 2.14). This dependency on Europe, which became a handicap once European growth began to slow, turned out to be an advantage when European growth accelerated, thus allowing PSA to avoid the negative effects of the emerging country crisis. This explains why PSA's foreign profits rose continually after 1993, enabling it 


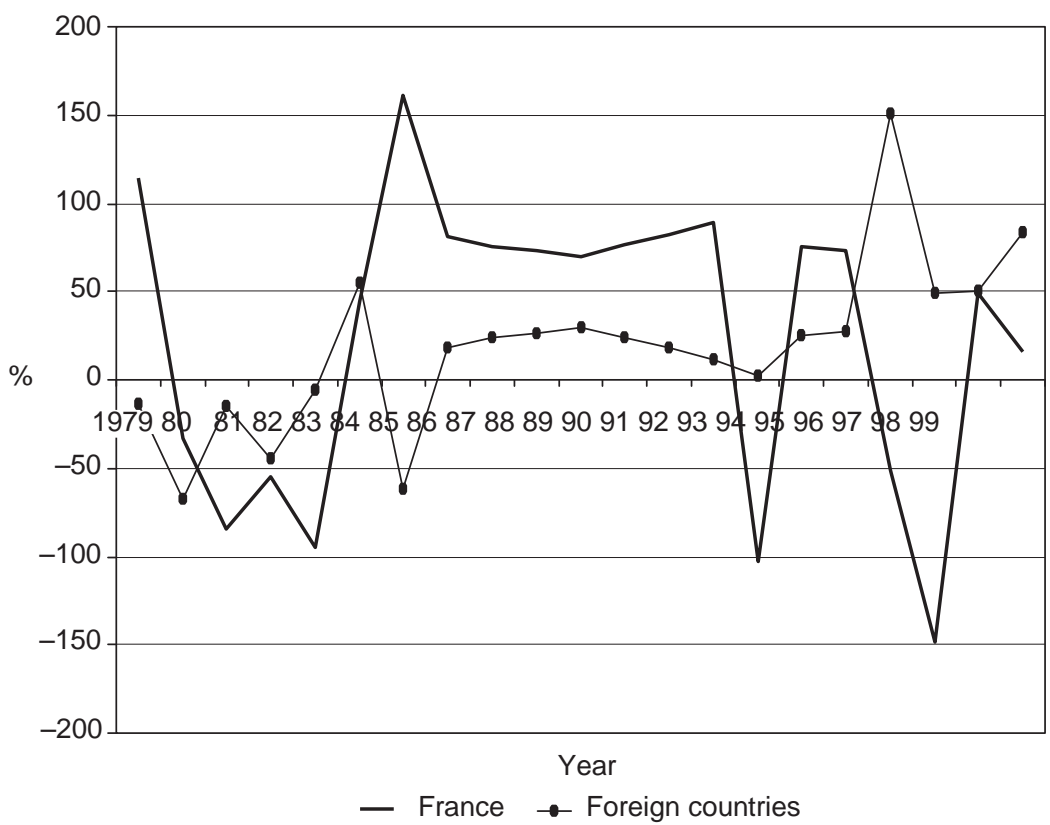

Figure 2.14 France's and foreign countries' contribution to PSA's operating profit, 1979-99

both to partially offset French losses in 1996-7 and to enjoy much higher world profits in 1998-9. However, such a favourable set of circumstances does not happen all that often, and the rest of the world's marginal but negative contribution to global profits $(-2 \%$ in 1985-99) represents a structural weakness (one that could, however, be overcome if PSA reinforces its presence in South America and Asia).

The Fiat Group's operating profits are also highly dependent on Europe, despite the geographical diversification efforts Fiat has undertaken. Over the period 1995-2000, European operating profits represented $66.2 \%$ of world operating profits compared to $33.8 \%$ outside Europe (including $18 \%$ for Mercosur, $16.7 \%$ in North America and $-1.1 \%$ in other countries). This limited diversification by the Fiat Group turned out to be very useful in overcoming the 1996 European recession (see Figure 2.15). A drop in operating profits from 2,500 billion liras in 1995 to around 1,000 billion in 1996 was offset by continued strong operating profits outside Europe (staying slightly above 1,000 billion liras; that is, around 500 million euros). However, the 1997 Asian crisis and its 1998 contagion to Mercosur highlighted the fragility of this result. In 1998-9, operating profits outside Europe were split in half and their contribution to world profits fell back to $30 \%$ (and then to 


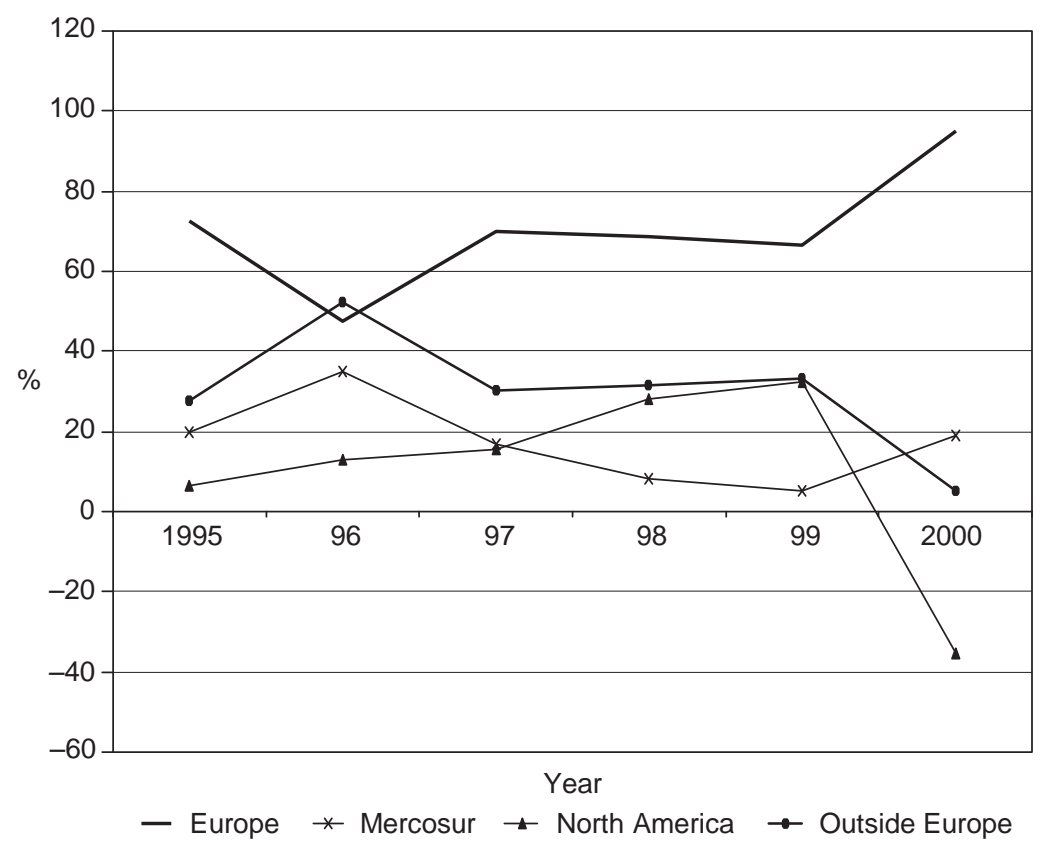

Figure 2.15 Europe's, Mercosur's and North America's contribution to the Fiat Group's operating profit, 1995-2000

$5 \%$ in 2000). These developments are explained by the collapse in North American profits, which had risen between 1995 and 1999, ultimately accounting for $32.5 \%$ of the Fiat Group's world operating profits - previously, North American profits had been able to offset a drop in earnings in Mercosur and in the other countries. As for Fiat Auto, the foreign profits' fragility has been aggravated by the absence of any profits in North America and by the fact that activities are concentrated in Europe and South America. Note that Fiat Auto suffers from chronic mediocre profitability in Europe. ${ }^{38}$ Although Fiat Auto's large profits during the Mercosur automobile market's growth phase (1994-7) made it possible to remedy this shortcoming, the 1998-9 Mercosur crisis exacerbated for Fiat Auto the effects of its shortfall in European profitability. As a result, Fiat Auto made an operating loss in 1998 and 1999, and only turned a small profit in 2000, a result of the cost savings generated by its new partnership with GM. Between 1998 and 2000 , the only profit sources were the group's non-automobile business, underlying the usefulness of the Fiat group's industrial and geographical diversification, as well as Fiat Auto's difficulty in sustaining a successful long-term emerging-country internationalization drive (even as European heartland profits were coming under attack). 
VW is a special case among European firms. Since 1970, VW has only experienced operating or net losses for the briefest of periods - during the three global recessions of 1974-5, 1981-2 and 1993. Since then, VW has broken all earnings records, moving from a 1993 operating loss of -1.6 billion DM to a 2000 operating profit of 6.7 billion DM, and from a net loss of -1.9 billion DM to a net profit of 4 billion DM. VW increased its internationalization efforts in Europe and across all continents of the world during this period, yet was not too severely hurt by the 1997-9 emergingcountry crisis. Over the period 1997-2000, VW's European operating profits represented $85.6 \%$ of its global operating profits. ${ }^{39}$ The remaining $14.4 \%$ included $16.9 \%$ in North America, $-2.4 \%$ in the 'South America and Africa zone', and finally $7.8 \%$ in Asia/Pacific. As demonstrated in Figure 2.16, VW's significant geographic diversification allowed it to overcome lower Asian earnings and losses in South America/Africa through a constant rise in North American profits (because of the success of the New Beetle, reinforced by the weakness of the euro against the US dollar), which jumped from $0.3 \%$ of world profits to nearly $17 \%$ in 2000 . In 1999, for example, losses of 710 million DM were offset by North American profits of 727 million DM. In addition, VW is one of the few firms to have made major profits in Asia/Pacific (2 billion DM over 1997-2000)

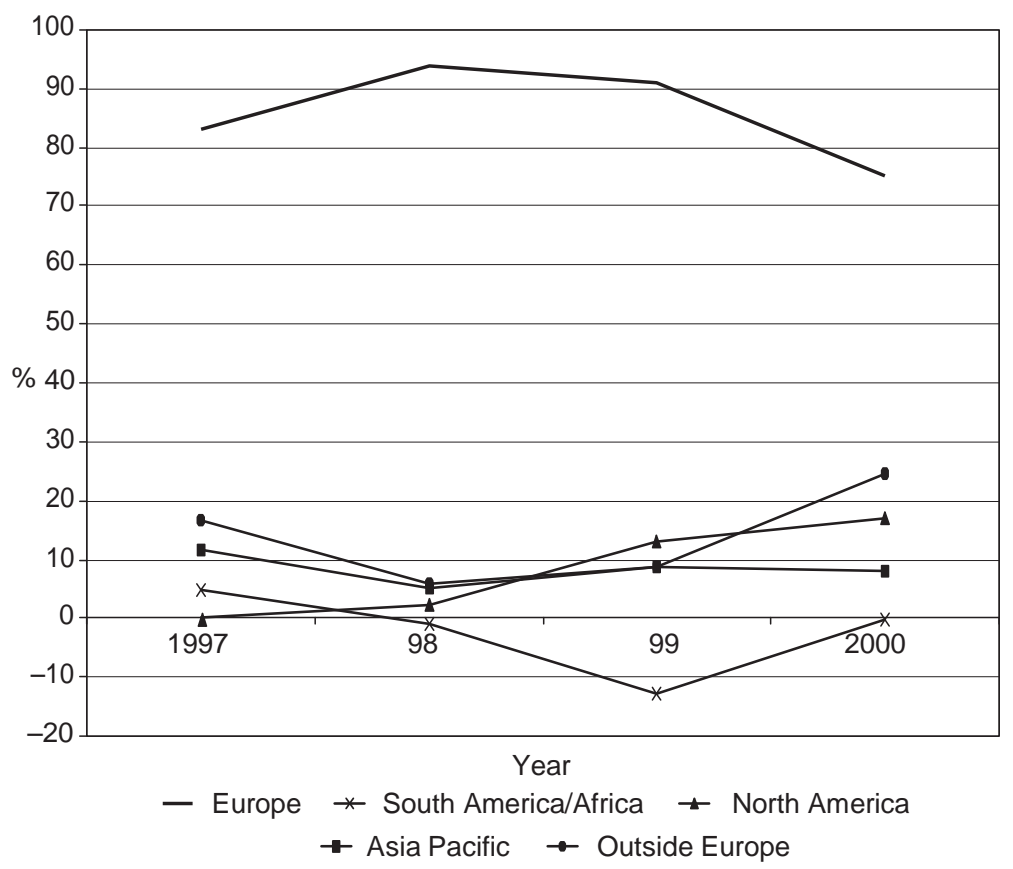

Figure 2.16 Europe's and other geographical areas' contribution to VW's operating profit, 1997-2000 

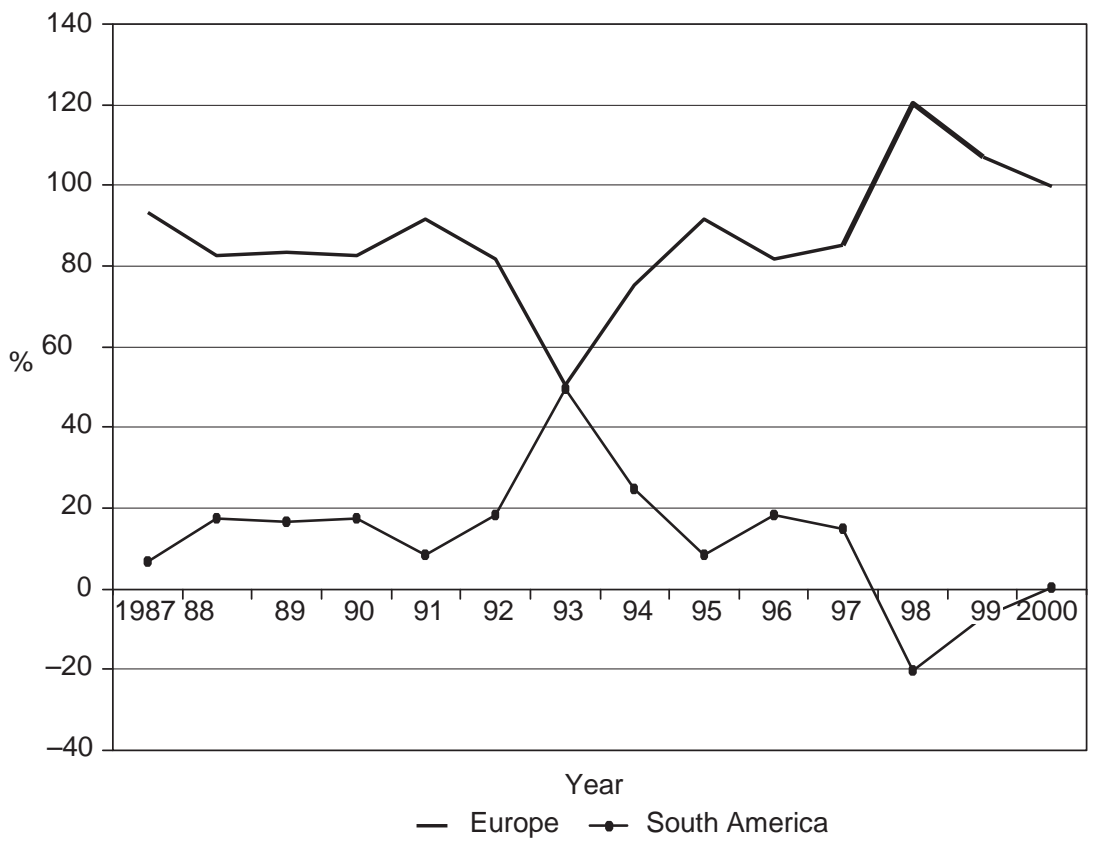

Figure 2.17 Europe's and South America's contribution to Scania's operating profit, 1987-2000

without having suffered any losses, even during the worst of the Asian crisis. Of course, the period under examination is very short, although it does cover a crucial time in the late 1990s crisis in the emerging countries (and in Japan). Still, our study does at least contain an example of successful internationalization, at least in profitability terms (as with Toyota and Honda).

Finally, Scania is another example of a successful internationalization (see Figure 2.17). A commercial vehicle specialist since 1991, Scania, like most capital goods producers is very sensitive to fluctuations in growth rates (since this sector tends to anticipate and accentuate recession and recovery phenomena).

Moreover, the only Scania facilities outside Europe, where the company realized around $16 \%$ of its production revenues in 1995-9, are found in Mercosur, a market characterized by great instability throughout the 1990s. In fact, Scania's global operating profits dropped from 3 billion to 1 billion kroners between 1989 and 1993; rose to 5 billion in 1994; suffered from the effects of the 1996 European recession; and finally recovered in 1997-9. In studying geographical contributions to Scania's global profits, note that, despite the highly unstable nature of the market, the firm did not experience any losses in 1987-97, either in Europe or in Mercosur. Europe accounted for around $82 \%$ 
of its world profits and Mercosur, the remaining 18\%. In 1993, Mercosur profits, which because of the general recovery in South America had just doubled their 1992 levels, helped Scania to cope with the recession that was just developing in Europe. Eventually, they accounted for $50 \%$ of Scania's world profits. Inversely, the 1998-9 Mercosur crisis created losses for Scania that reached $20 \%$ in 1998, but these were largely offset by higher earnings in Europe.

\section{Conclusion}

Although the information at our disposal was neither exhaustive nor homogeneous for all the automakers, the following lessons can nevertheless be derived from our analysis of levels of internationalization:

1. Automobile firms, perhaps with the exception of Honda, are not global firms. Commercial internationalization is by far the most advanced with Japanese (57\%) and European (73\%) firms, but for the Americans $(24.5 \%)$ the focus of activity remains their domestic market. The large size of the American market does not explain all this, given that the European market now accounts for equivalent volumes (around 20 million units per year). Productive internationalization outside a firm's country of origin remains below $45 \%$ on average according to our production revenue criterion. Moreover, according to our overseas production criterion, it only surpasses $50 \%$ in Europe. ${ }^{40}$ Capital internationalization is even less developed - foreign assets only represent $30 \%$ or less of American or Japanese firms' total assets (although this number does rise to $54 \%$ for European firms). Table 2.7 provides a synthesized vision of the various forms of internationalization by means of a synthetical global index, which adds the proportion of overseas production to the synthesized UNCTAD index we have shown for comparative purposes. ${ }^{41}$ Globally, we find that the average level of internationalization is $43.2 \% ; 50 \%$ of all firms feature a level of internationalization of more than $41.5 \%$, and only five out of sixteen firms feature an internationalization of more than $50 \%$, regardless of the index being used. This includes three European and two Japanese firms that are not necessary the largest ones in terms of their overall production volumes. These firms also have in common the fact that they market least a quarter of their revenues and manufacture at least a quarter of their output outside their region of origin. ${ }^{42}$ Toyota and the Fiat Group, with a global index of around $47 \%$ and UNCTAD index values of $52 \%$ and $49 \%$, respectively, are very close to this leading group, and present similar characteristics. But we cannot call the seven most internationalized firms 'global firms'; instead, they should be called multiregional firms, given that they run at least one major facility on another continent (Honda, Toyota, Nissan and DaimlerChrysler) or else several significant but smaller facilities on different continents (VW). The new 
Table 2.7 Ranking of firms according to the synthetical indexes

\begin{tabular}{lcc}
\hline Firms & Global & UNCTAD \\
\hline DaimlerChrysler (97-99) & 69.8 & 67.4 \\
Honda (95-99) & 60.7 & 65.3 \\
BMW (95-99) & 56.0 & 58.3 \\
VW (95-99) & 55.8 & 56.6 \\
Nissan (95-99) & 51.1 & 54.9 \\
Fiat Group (95-99) & 47.2 & 49.2 \\
Toyota (95-99) & 46.8 & 52.1 \\
Isuzu (96-99) & 41.9 & 41.9 \\
Renault (95-99) & 41.2 & 45.8 \\
Ford (95-97) & 38.6 & 36.1 \\
PSA (95-99) & 36.8 & 41.4 \\
Mitsubishi (95-99) & 35.6 & 37.5 \\
GM (95-96) & 33.8 & 30.0 \\
Subaru (95-99) & 32.3 & 37.6 \\
Mazda (95-99) & 29.9 & 33.8 \\
Navistar (96-98) & 13.7 & 9.5 \\
Average & $\mathbf{4 3 . 2}$ & $\mathbf{4 4 . 8}$ \\
Median & $\mathbf{4 1 . 5}$ & $\mathbf{4 3 . 9}$ \\
\hline
\end{tabular}

Source: Our own calculations from the firms' financial reports. For methodology see Table 2.2.

merger/acquisition or partnership projects, which can be based on capital stakes being taken with or without a controlling participation, presuppose that the internationalization trend will continue, but that it will sometimes take the shape of original forms that will make it more difficult to identify the exact dimensions of the new entities being created. ${ }^{43}$ The profitability of this new stage of internationalization also raises a number of issues, especially since it has been shown that those firms that are the most internationalized are not necessary the most profitable.

2. We note that few firms have succeeded in transforming foreign operations, all regions combined, into a durable source of profit. Among the American firms, and unlike Ford, GM (despite the fact that it has long been described as a leader in decline) was able to achieve this not only during long postwar period of high growth but also over the course of two decades (1980-2000) of slow and unstable growth. In Japan since the 1980s only Toyota, Honda and Suzuki were able to achieve this. All the other Japanese firms' performances were either mediocre (Subaru, Isuzu) or even negative (Mazda, Mitsubishi, Nissan). In Europe, French firms have only been making a profit on their foreign operations since 1986. Scania (and probably VW) had similar results. Table 2.8 provides a synthetical view of this result 
Table 2.8 Number of loss-making years, 1990-9, by geographical zone

\begin{tabular}{lccc}
\hline Firms & Overseas & $\begin{array}{c}\text { Country } \\
\text { of origin }\end{array}$ & World \\
\hline Toyota & 0 & 0 & 0 \\
Honda & 0 & 0 & 0 \\
Suzuki & 0 & 0 & 0 \\
VW & probably 0 & 1 & 1 \\
Renault (1990- & 0 & 3 & 1 \\
8) & 0 & 3 & 2 \\
PSA & 0 & 4 & 3 \\
GM & 2 & 0 & 0 \\
Scania & 5 & 2 & 1 \\
Isuzu (1994-9) & 5 & 3 & 2 \\
Ford & 5 & 3 & 4 \\
Subaru & 6 & 1 & 1 \\
Mitsubishi & 6 & 4 & 7 \\
Nissan & 7 & 2 & 5 \\
Mazda & & & \\
\hline Source: Our own & calculations from & the firms' & financial \\
reports. & & &
\end{tabular}

for 1990-9, a period covering an entire cycle of growth in North America; a period of slow growth and then recovery in Europe; ${ }^{44}$ and the beginning of an extended period of stagnation in Japan. Seven out of thirteen firms did not make any foreign losses at all over this decade, including three Japanese, three Europeans and one American. These are firms for which internationalization has generally developed into an additional competitive advantage. The three Japanese firms present the particularity of not having suffered any losses in their market of origin, in spite of the Japanese economic crisis and the country's weaker automobile market. In Europe, only VW has achieved a similar performance. French firms and GM only lost money in their domestic markets, and this was offset occasionally by foreign profits. Scania is close to this first group - the Mercosur crisis caused it to lose money for two years in its number two market, yet it did not record any overall losses, coming out ahead both in its market of origin and globally.

This initial category is followed by a group of firms (almost all of whom are Japanese) that lost money during at least half of the 1990s, something that cannot be explained solely by short-term fluctuations. For these firms, internationalization has represented a handicap that has often compounded a precarious national situation.

Ultimately, we know that there is no clear and linear relationship between levels of internationalization and profitability. Honda, VW, and 
to a lesser extent Toyota, are members of a category comprised of the world's most internationalized firms (using a classification derived from synthetical indexes) but Renault and PSA are not really members of this group (given their average level of internationalization), and GM even less so. ${ }^{45}$ Similarly, within the group of those firms for which internationalization has been the least successful, we find relatively lessinternationalized firms such as Mazda, Mitsubishi and Subaru as well as a firm that is highly internationalized (Nissan). A firm can fail as a result of insufficient internationalization (that is, Mazda) or else because of its high but inappropriate degree of internationalization (that is, Nissan). In the same vein, a firm can obtain profits from abroad because it has a low level of internationalization (PSA) - or else its higher level of internationalization can expose it to greater possibilities of losses (Fiat Auto). Internationalization is truly a risky business, and not always a source of advantage. More than the actual level of internationalization, it is the quality of this status, its appropriateness to the firm's specific resources, to the competitive environment and to the characteristics of market demand that leads to success or to failure - an observation that raises questions about the organizational characteristics of those firms that have been the most successful.

3. The three firms (Toyota, Honda and VW) whose productive models have turned out to be the most relevant and coherent (Boyer and Freyssenet, 2002) are among the most internationalized firms of all (Honda and VW) or at least belong to the upper tier in this category (Toyota). These are firms where internationalization has become a durable source of profit. Should we consider this to be a confirmation that their respective productive models, built within a national framework, have been reinforced by the international situation post- 1974? The figures sustain this thesis but do not suffice to prove it. Indeed, when these firms internationalize, their national productive model undergoes an inevitable hybridization that can vary depending on the region in which they have set up facilities. This hybridization affects their initial 'profit strategy' and 'company government compromise' - these being the two preconditions for a firm's profitability. Will Honda be able to pursue its 'innovation - flexibility' strategy in those regions where it has set up operations, or else is it going to change strategy? If so, how can we be certain that the successes these firms have achieved abroad are the consequence of an original productive model? Might they not be a hybrid variant that is quite distinct from the original model? To answer these questions, we need a specific in-depth analysis of firms' internationalization trajectories - something that can be found in the later chapters of this book. 


\section{Methodological appendix}

\section{Sources}

National and world production data of automobile firms are taken from: 'L'industrie automobile française', several years completed by le Répertoire Mondial des activités de production et d'assemblage des véhicules automobiles, CCFA, 2 rue de Presbourg, 75008, Paris, France (www.ccfa.fr). All other data are taken from the financial reports published by firms every year.

\section{Contribution index to world profit}

We have tried to determine whether national or foreign profit contributed to increasing or decreasing world profit, or to reducing/worsening world loss. To do so, we have divided the foreign profit or loss by the absolute value of the world profit or loss. We have done the same with the national profit or loss. We can therefore take into account all possible cases.

Two examples are given here:

1. If the national and foreign profits are worth 50 each, world profit is worth 100 , and the contribution of national and foreign profit is $50 \%$.

2. If national profit is worth 50 , and a foreign loss worth -70 is registered, there is a world loss of -20 . The contribution of national profit is 50 divided by the absolute value of -20 , (equal to 20), which gives a positive contribution of $250 \%$. The negative contribution of the foreign loss is -70 divided by 20 , which gives $350 \%$. Finally, the sum of the contribution of the national profit $(250 \%)$ and that of the foreign loss $(-350 \%)$ gives a negative balance of $-100 \%$, pointing to the fact that the firm has suffered a world loss. The national profit has contributed to reducing this world loss; but the foreign loss has contributed to worsening it.

We can also imagine the case of a world profit resulting from a foreign profit despite a national loss, and so on.

\section{Notes}

1 Unfortunately, we have not got at our disposal sufficient information on Fiat or the German firms.

2 The transnationality index is calculated as an average of three relationships: foreign assets versus total assets; foreign sales versus total sales; and foreign staff versus total staff (cf. UNCTAD, 1999).

3 GM, Ford, Toyota/Daihatsu/Hino.

4 GM (Isuzu included), Ford (Mazda included), Toyota/Daihatsu/Hino, DaimlerChrysler, Renault/Nissan, VW.

5 Nissan and VW.

6 Fiat, PSA, Honda, Mitsubishi.

7 Chrysler, Renault, PSA, UAZ, Fiat, Honda, Mazda, Mitsubishi.

8 Suzuki-Maruti, Hyundai-Kia-Asia, Daewoo-Ssangyong, Avtovaz.

9 Suzuki, Daimler-Benz, Isuzu, Subaru, British Leyland, Volvo, BMW.

10 Avtovaz, Subaru, Volvo, Proton, Gaz, ChinaFirst.

11 The 'commercial revenues' indicator allows us to break world sales down into their component parts (all products combined) by place of sale, regardless of 
where the product was manufactured. A product can be sold in a given foreign country after being made in the firm's country of origin or in third country.

12 The 'production revenues' indicator allows us to break global sales down into their component parts (all products combined) by the location in which the firm's subsidiaries have set up operations. One product can be manufactured by an overseas subsidiary of the firm, and sold in the same country, or in another country.

13 These are personal calculations based on the fifteen automobile firms that appear among the 100 leading multinationals comprising the UNCTAD sample.

14 Korean firms were not included because of the insufficiency and unreliability of relevant statistical information. The same applies to Russian, Chinese and Indian firms. Often smaller than average, these firms are barely internationalized and their future as independent concerns remains in question, particularly in South Korea.

15 This number can be obtained from the average of Averages (1), (3) and (5). (See Table 2.2.)

16 During the 1970s, North America was limited to the United States and Canada. Since the creation of NAFTA, however, Ford includes Mexico as part of North America.

17 In 1990-9, 69.8\% for NAFTA, 23.7\% for Europe and $6.5 \%$ for the rest of the world, including around $3 \%$ in South America and $3.5 \%$ in Asia/Africa/Pacific. Sources: personal calculations based on financial statements.

18 Like Paccar and Navistar (see Table 2.2) and in particular the Japanese commercial vehicle makers. Hino, Japan's top automaker, made only $12 \%$ of its total sales overseas in 1998-9.

19 Fiat's example shows the usefulness of industrial diversification, as $6.8 \%$ of the group's revenues in North America are not made by Fiat Auto, the group's passenger car subsidiary, but by other units within the group.

20 French firms, for example, make $25 \%$ of their total sales outside Europe.

21 By the year 2010, GM plans to realize $10 \%$ of its total sales in Japan.

22 If we include the Korean firms, overseas production reached an average of $24 \%$ in $1990-4$ and $36.3 \%$ in $1995-9$.

23 As a result, BMW's percentage of overseas production dropped sharply below $50 \%$ in 2000.

24 Here we are defining the term 'region' in the broadest sense of the term. For American firms, this means NAFTA plus South America. For European firms, it is the European Union (EU) plus other countries in Europe (including Turkey). For Japanese firms, it means the other countries in Asia, plus Oceania and Africa.

25 That is, outside NAFTA and South America.

26 Here we could mention the Renault/Nissan grouping, linked to the Volvo/ $\mathrm{RVI} /$ Mack/Nissan Diesel grouping; DaimlerChrysler/Mitsubishi; and other groupings such as VW/Scania and GM/Fiat (or even the take-over of Navistar by Hino).

27 Sales by zone of production is a measurement that includes all the products (complete passenger cars, commercial vehicles where applicable, motorcycles, motors and spare parts) that are used in all the business lines (automobiles, other manufacturing activities and services).

28 The periods that Tables 2.2 and 2.6 cover in terms of commercial revenues and production revenues are different from the ones referred to here, since information on breakdown by geographic zone has only been available since 1997 for Japanese firms (with VW and Renault no longer providing this information from 1997 and 1998 onwards, respectively). Generally speaking, this has had a minimal impact on the exportable surpluses (commercial revenues production revenues) that we have calculated. 
29 The revenues 'produced' by foreign subsidiaries (see revenues by production facility, Tables 2.2 and 2.6) modify the hierarchy of productive internationalization (when measured by overseas production and calculated in physical terms). This applies mainly to European firms. Several reasons explain this phenomenon: the nature of the product range that is being manufactured; average purchasing power in each operational zone; the foreign production's rate of integration; variations in exchange rates and so on. There is not enough space in this chapter to do justice to all these considerations.

30 For the American and Japanese firms, we can make use of long series of net profit statistics. For European firms, we have series of varying lengths covering operating profits. These two measurements of profit are clearly not the same. The point, however, is not to compare them, but instead to study, with the help of our indicator, overseas contributions to profits.

31 To analyse Japanese firms' world profits, we dispose of two sources of information. On the one hand, we have net consolidated world-wide earnings, and net unconsolidated earnings (reflecting changes in Japan itself). To calculate net foreign earnings, we subtract net unconsolidated earnings from net consolidated earnings. Using these two time series we calculate an indicator of contributions by net national and foreign profits to net world profits. This is, of course, a rough assessment, but it is an accurate one that is particularly useful in analysing long term trends. In addition, we can break operating profits down by geographic zone from around 1995-6 onwards. By definition, operating profits are a truer reflection of a firm's productive activities - but our information is more recent. Net profits, which include financial income and charges, tax, and extraordinary income and costs, reflect a firm's final earnings. We have tried to combine the two sets of information. The only numbers represented in graphic form are changes in net profits.

32 The sharp drop in Honda's net earnings in Japan are explained by an exceptional domestic loss of 109.4 million yen.

33 Reuters interview with M. Davies, General Manager Honda UK, 21 December 2000, http:/just-auto.com/features.

34 US sales reached a peak of 183,000 units in 1986 and fell to a low of 100,000 in 1995 before going back up to 172,000 in 2000 thanks to a rejuvenated product range.

35 In 2000, Mitsubishi's sales in Japan suffered as a result of a scandal involving the recall of faulty vehicles. Passenger car and truck sales fell by $8.6 \%$, and mini-car sales by $7 \%$.

36 Its subsidiary in Thailand suffered a loss of 43.7 billion yen (around US $\$ 350$ million) caused by the impact of the baht devaluation on dollar-linked debt (and because of the collapse of the local market).

37 Operating profit is the only geographical zone information available on European firms. Renault and PSA stopped publishing this data in 1998. Fiat and VW started to publish it in 1995 and 1997. Volvo does not publish it at all.

38 Despite major productive modernization initiatives during the 1990s, Fiat Auto is still handicapped by its specialization ( $70 \%$ of the firm's sales) in a small-car sector that is marked by weak profit margins. The firm does not achieve sufficient economies of scale compared to its European rivals. Turnover was increased by a factor of 1.8 between 1990 and 2000 but operating profits never returned to the level they had reached in the late 1980s.

39 To break the VW Group's pre-tax operating profits down on a geographical basis, we have used the following method (based on the segment analysis contained within the company's annual report): (i) we use only gross profits for manufacturing activities, thus excluding financial activities; and (ii) we consider that each 
marque (VW, Audi, Skoda, Seat, Rolls-Royce/Bentley) made its profits in Europe, with the world's 'other regions' being presented as such in the report.

40 If we exclude firms specializing in commercial vehicle production, overseas manufacturing represents around $45 \%$ of world output for European and American firms, but only $31 \%$ for Japanese firms (see Averages (2), (4) and (5) in Table 2.2).

41 We have sometimes supplemented the UNCTAD calculations, for example, by incorporating Honda Motor's number of overseas staff members. Where information is lacking on assets or staffing, we did not calculate the UNCTAD index, in contrast to the UNCTAD itself, which calculates this index even when it only has available two out of the three necessary pieces of information.

42 Apart from BMW, which has an extra-European production of only $6.3 \%$, BMW's 2000 divorce from Rover does not seem to have undermined the group's level of internationalization. Quite the contrary, in fact: it diminishes Europe's role. BMW has continued to stress its internationalization drive in North America, with the proportion of total assets located in this region rising from $23.7 \%$ in 1999 to $30.3 \%$ in 2000.

43 For example, there was no ambiguity during the DaimlerChrysler merger, given the length of time that the illusion of a 'merger among equals' lasted. Less straightforward was the take-over of Mitsubishi by DaimlerChrysler, and of Nissan by Renault. Although there is no ambiguity with respect to the leading role played by DaimlerChrysler and by Renault in these operations, the new groupings do not (yet?) constitute jointly operating firms, and may never reach that stage. The Fiat/GM agreement (not to mention the increased number of ad hoc partnership arrangements) raises the same types of issue.

44 This is the only period where available information allows the comparison of the greatest number of firms.

45 We have not been able to calculate the synthetical index for Scania and Suzuki, since one of the necessary pieces of information is not available. Based on three elements out of four, Scania's overall synthetical index value is $71.5 \%$, and Suzuki's $35.2 \%$.

\section{References}

Boyer, R. and Freyssenet, M. (2002) The Productive Models: The Conditions of Profitability, London/New York: Palgrave.

Chesnais, F. (1994) La mondialisation du capital, Paris: Syros.

Economist Intelligence Unit (2000) The Automotive Industries of Asia-Pacific:

Prospects for ASEAN and the emerging markets to 2005.

Economist, The (1999) 'How to Make Mergers Work?', The Economist, 9 January.

Financial Times Auto Survey (2000) 'Brazil: Sights Set to Give Exports Needed Boost'.

Website: www.ftsurveys/industry/sccc0a.htm.

Friedman, J. (1983) Oligopoly Theory, Cambridge University Press.

Lung, Y. (2000) 'Towards a Worldwide Oligoply in the Automobile Industry?', La Lettre du GERPISA, no. 143, June. Website: www.gerpisa.univ-evry.fr

Ohmae, K. (1985) Triad Power, New York: The Free Press.

Porter, M. (1986) Competition in Global Industries, Boston, Mass.: Harvard Business School Press.

PricewaterhouseCoopers (1999) Global Automotive Industry Review 1998.

UNCTAD (1998) World Investment Report: Trends and Determinants, New

York/Geneva: United Nations. 
UNCTAD (1999) World Investment Report: Foreign Direct Investment and the Challenge of Development, New York/Geneva: United Nations.

UNCTAD (2000) World Investment Report: Cross-Border Mergers and Acquisitions and Development, New York/Geneva: United Nations.

Ward's Automotive Yearbook (2000). 